\title{
Financial Development, Internationalisation and Firm Value
}

\section{Thomas O'Connor}

\begin{abstract}
In this article I show that both aspects of financial development, namely, liberalisation and deepening, and financial internationalisation proxied using crosslistings in the US creates value for emerging market firms. Financial deepening, or more precisely, stock market deepening enhances value. In contrast, bank sector deepening only serves to reduce value because it is associated with large-scale corporate expansion and a fall in market capitalisation. Like others, I document a cross-listing premium for Level 2/3 cross-listings in the US. The cross-listing premium is typically less than the gains from financial liberalisation, but they are similar in magnitude over the period examined.
\end{abstract}

\section{JEL Classification: G15, F36}

Keywords: Financial liberalisation, financial deepening, internationalisation, Tobin's $q$

\section{Introduction}

Since the seminal work of Fazzari et al. (1988), much work has sought to explain why firms are financially constrained. Firms are deemed financially constrained if a windfall increase in the supply of internals funds leads to higher investment outlay. Recent work suggests that the types of firm that are most constrained tend to be small, non-listed, non-group nor foreign owned, national (as opposed to multinational) and government owned (Beck et al. 2006), and the sources of these constraints tend to be financial (e.g., high interest rates, poor access to long-term loans, little or no access to foreign banks), legal (e.g., inefficient legal system, poor enforcement of contracts) and institutional based (e.g., corruption, regulatory quality, political stability) (Beck et al. 2005; Beck et al. 2006; Beck and Demirguc-Kunt 2006). Furthermore, since financial, legal and institutional development tends to

Journal of Emerging Market Finance, 10:1 (2011): 21-71

SAGE Publications Los Angeles London New Delhi Singapore Washington DC DOI: $10.1177 / 097265271101000102$ 
be more advanced in developed as opposed to emerging countries, financing constraints tend to be more severe in the latter (Beck et al. 2006; DemirgucKunt and Maksimovic 1998). The general conclusions from this line of work suggest that both firm- and country-level factors explain firm-level financing constraints that they tend to complement one another (e.g., on average a small firm is even more constrained where the banking sector is poorly developed), and of the country-level factors, institutional development, or more precisely the lack of, tends to have the greatest impact on retarding firm-level growth. Of course, this then suggests that country-level attempts to foster financial, legal and institutional development are likely to lower firm-level financing constraints, increase investment and promote growth.

Given the perceived benefits that arise from financial development, it is perhaps not surprising that countries have initiated a number of financial sector reforms in an attempt to realize these gains. Collectively, these reforms are often referred to as financial liberalisation. These policies include the strengthening of financial sector supervision and regulation, privatisation of the domestic banking sector, where foreign banks were now permitted to participate, stock market liberalisations and concurrent reforms, and the reduction in barriers, which prevented the flow of capital internationally. While the introduction of these reforms does not come about without some short-term costs (e.g., higher incidence of banking crises; DemirgucKunt and Detragiache 1999), and greater output volatility (Kaminsky and Schmukler 2008), recent work suggests that such liberalisation policies are associated with long-term net benefits at the overall macro economy level (Kaminsky and Schmukler 2008; Levine 2001). ${ }^{1}$ In turn, these policies have tended to succeed in exactly what they set out to do, i.e., deepen financial markets (equity and banking/credit markets), ${ }^{2}$ although as shown by Tressel and Detragaiche (2008), financial liberalisation only serves to

\footnotetext{
${ }^{1}$ A large literature has tried to explain such boom-bust behaviour in the aftermath of financial liberalisation reforms. For example, Allen and Gale (1999, 2000) and Schneider and Tornell (2004) show that financial liberalisation leads to riskier behaviour by banks.

${ }^{2}$ A large literature exists which examines whether stock and bank-sector development contributes to the growth of the real economy (Beck and Levine 2004; Levine 1991, 1998; Levine and Zervos 1998). The recent work, which is robust to many of the econometric issues that plagued earlier studies, suggests that both stock markets and banks positively influence growth. A related line of work shows that the development of stock markets need not necessarily adversely affect the banking sector (Demirguc-Kunt and Levine 1996).
} 
promote financial deepening where institutions are sufficiently developed to curb political power, which is consistent with the line of reasoning presented earlier. ${ }^{3}$ Together, both aspects of financial development, namely, liberalisation and deepening have served to provide sizable benefits at the firm level, although they have tended to benefit smaller firms more (Beck et al. 2008; Christoffersen et al. 2006), since financial liberalisation results in a fairer allocation of capital between small and large firms (Abiad et al. 2004). ${ }^{4}$ Collectively, financial development has resulted in greater access to external financing, resulting in a relaxation of financing constraints, improved operating performance, which ultimately has led to greater externally financed growth for these firms (Khurana et al. 2006; Laeven 2003; Love 2003; Mitton 2006; Rajan and Zingales 1998 for studies which examine the impact of financial liberalisation/deepening/development on firms).

In addition to the reform measures enacted at the country level, at the firm level, firms have augmented these country-level reforms with liberalisation events, collectively known as 'internationalisations', in order to further reduce their financing constraints and further their growth. Much of this 'internationalisation' activity that has come after domestic financial development is well advanced, and has generally taken the form of international cross-listings, especially in the US, and international capital raising activity. ${ }^{5}$ For example,

\footnotetext{
${ }^{3}$ Entirely consistent with this line of reasoning, others have shown that in some countries, liberalisations have provided limited stock market development, and in some instances, have actually led to a deterioration in market performance (de la Torre and Schmukler 2006). Also, a large literature shows that other factors also matter for stock market development (Billmeier and Massa 2009; Boyd et al. 2001; De la Torre et al. 2007; La Porta et al. 1997, 1998; Li 2007). For example, Rajan and Zingales (2003) and Claessens et al. (2006) show that more developed countries tend to have deeper stock markets.

${ }^{4}$ Financial liberalisation generally refers to reform which result in a lower degree of government involvement, which ultimately leads to a more market-based financial system. Alternatively, financial deepening refers to increases in volumes of markets, e.g., liquidity, market capitalisations, lending in the case of banking/credit markets.

${ }^{5}$ Claessens et al. (2006) and De la Torre et al. (2007) show that stock market development also promotes internationalisation, which has the potential to offset some of the gains from earlier liberalisation reforms. In a similar vein, Levine and Schmukler (2007) show that internationalisation is negatively related to the trading activity of domestic firms that refrain from becoming 'international' firms, and in a related paper, show that the domestic trading of firms that cross-list 'migrates' to international exchanges, once these firms internationalise. See also Moel (2001) and Karolyi (2004) who examine the relationship between American Depositary Receipt issuance and stock market development in emerging markets.
} 
between 1990 and its peak in 2000, the number of exchange, i.e., Level 2/3 ADRs increased from 176 to 608, while the number of non-exchange listings, i.e., Level 1 and Rule 144a lists, is even greater. In addition, Gozzi et al. (2010) show that international capital raisings has increased fourfold since 1991, resulting in about 30 per cent of all capital raised by firms being raised internationally. Subsequent work has shown that such actions by firms have by and large been successful. For example, 'internationalisation' has lowered firms' cost of capital, reduced their financing constraints, ultimately facilitating corporate growth and expansion, both at home and abroad (Khurana et al. 2008; Lins et al. 2005; Reese and Weisbach 2002).

A concurrent line of research has focused on how these programmes, given their positive impact on operating performance and growth, ultimately impact on firm value. A priori, since the earlier mentioned benefits from liberalisation and internationalisation reforms are likely to influence firm size and stock prices, it is not altogether obvious how such reforms impact on firm value. A large and still growing literature has examined whether cross-listing in the US, and elsewhere, manifests into a cross-listing premium for cross-listing firms. The evidence is mixed. While there appears to be consensus agreement that a cross-listing premium exists, although perhaps not for cross-listings in the UK (Doidge et al. [2009] find that there is not, Bianconi and Tan [2010] conclude otherwise), there is general disagreement about the durability of this premium. Doidge et al. (2009) suggest that it is permanent, while others suggest that it is transitory (Gozzi et al. 2008; Sarkissian and Schill 2009, 2010). ${ }^{6}$ In a similar vein, Mitton and O'Connor (2010) find that investability (i.e., a firm-level measure of stock market liberalisations, and thus one aspect of financial liberalisation) also increases firm value. Thus, while it is generally well accepted that 'internationalisations' and some aspects of financial liberalisation impact positively on firm value, very little is known about how financial liberalisation as a whole, and other components of liberalisation, impact firm value. ${ }^{7}$ Furthermore, no study has ever examined, to the best of my knowledge, how financial deepening, as opposed to liberalisation, impacts on firm value. Finally, since the valuation gains from financial development, i.e., financial liberalisation and deepening have not

\footnotetext{
${ }^{6}$ For a review of the legal bonding hypothesis, see Benos and Weisbach (2004), Ferris et al. (2009) and Karolyi (2006, 2010).

${ }^{7}$ Others disagree. They suggest that an international listing, e.g., in the US, does not have permanent positive valuation gains for firms (Gozzi et al. 2008; Sarkissian and Schill 2009, 2010).
}

Journal of Emerging Market Finance, 10:1 (2011): 21-71 
yet been fully investigated, we know little or nothing about how the gains from financial development and internationalisations compare to one another. Here, in this article I attempt to fill this void.

To do so, I examine how financial liberalisation, financial deepening and internationalisations impact on the value of 2,899 emerging market firms over the period from 1982 to 2002. I follow others (Doidge et al. 2004, 2009; Gozzi et al. 2008; Mitton and O'Connor 2010) and measure firm value using Tobin's $q$. I measure financial liberalisation using the recently updated index created by Abiad et al. (2008). I prefer to use this index over others (Kaminsky and Schmukler 2008; Laeven 2003) since this index allows for reversals in financial liberalisation. ${ }^{8}$ Similar to others (Schmukler and Vesperoni 2006), I measure financial deepening as the sum of stock and bank sector deepening. In turn, stock market deepening is measured as stock market capitalisation to GDP, and bank sector deepening is measured as liabilities of the banking sector, as a percentage of GDP, respectively. Finally, I define internationalisations using firms that cross-list in the US.

Using a series of firm fixed effects regressions, I show that financial development impacts on firm value, via both financial liberalisation and financial deepening. However, the valuation gains from financial deepening are much larger, and arise solely from equity/stock market deepening. In contrast, bank sector deepening reduces firm value, mainly because it is associated with large-scale corporate expansion. Similar to others, I document a cross-listing premium for Level $2 / 3$ lists in the US. This premium tends to be of the same magnitude as the gains from financial liberalisation over the sample period, although large-scale financial liberalisation programmes typically imply larger increases in firm value. Finally, on further inspection of the components of Tobin's $q$, I find that the valuation gains from financial liberalisation arise from a reduction in firm size, and a concurrent increase in market capitalisation. Since I am using the Worldscope database, which is generally made up of the largest firms in each country, the former is consistent with the notion that

${ }^{8}$ Laeven's (2003) financial liberalisation index covers six reform measures, namely, interest rate deregulation, reduction of entry barriers, reduction of reserve requirements, reduction of credit controls, privatisation of state banks and strengthening of regulation. The index is increasing in financial liberalisation and ranges from 0 to 6 . The major flaw with this index is that it does not account for reversals in financial liberalisation. The Kaminsky and Schmukler (2008) Index ranges from 0 to 3 , is decreasing in financial liberalisation, and covers capital account, domestic financial sector reform and stock market reforms. Similar to Abiad et al. (2008), the index allows for reversals in the liberalisation process. 
financial development disproportionately benefits small firms, thus promoting their growth and slowing the growth of large firms (i.e., liberalisation lowers firm size and deepening increases firm size, but growth ultimately slows; Costantini 2008).

This article makes a number of different contributions. First, I extend the literature which examines how financial sector reforms and internationalisations impact the firm value. I extend Mitton and O'Connor's findings (2010), and show that other aspects of financial liberalisation and financial development as a whole impact on firm value. Second, this article also contributes to the literature, which compares the liberalisation and deepening processes. Abiad et al. (2004) demonstrate how financial liberalisation, and not deepening, serves to improve the allocation of capital between small and large firms. I show that both matter, but financial deepening matters the most. Third, this article also analyses how domestic market reforms and financial internationalisation (at the firm level) compare in their effects on firm value. Along these lines, Schmukler and Vesperoni (2006) find that domestic financial reforms and financial globalisation (measured using access international debt and equity markets, e.g., ADRs) have very different effects on the maturity structure of corporate debt. Flavin and O'Connor (2010) show that liberalisation reforms, i.e., stock market liberalisations and crosslistings impact similarly on corporate capital structure, but firms that were previously investable (through stock market liberalisations) behave differently once they cross-list to cross-listing firms that were previously not investable. I find that the gains from cross-listing on a US exchange are similar in magnitude to the gains arising from financial liberalisation over the sample period, although financial liberalisation typically implies larger increases in firm value. Finally, these results suggest that firms would gain more, at least in terms of value, not from cross-listing abroad, but from policy issues that promote financial deepening at home.

The article proceeds as follows. Next, I describe the data. Section 3 presents the regression specifications and a discussion of the results. Section 4 concludes.

\section{Data Description}

I begin this study by sourcing a full list of emerging market firms from the country lists of the Worldscope database. To ensure that my article is directly comparable to Mitton and O'Connor (2010), I use the same sample 
of countries that they employ. Using this sample of firms, I drop firms with missing data, firms with two or less observations and financial firms, since these firms are likely to be valued differently to non-financial firms. Excluding financial/banking firms from my sample is of little concern to me, since I am interested in how, amongst others, banking-sector reforms impact on the value of non-financial firms. After imposing these data requirements, my final sample is made up of 2,899 firms from 20 emerging market countries. They are Argentina, Brazil, Chile, China, Colombia, Greece, India, Indonesia, Israel, Korea (Republic), Malaysia, Mexico, Pakistan, Peru, Philippines, Portugal, South Africa, Taiwan, Thailand and Turkey. While my sample undoubtedly contains countries that are no longer seen as emerging (e.g., Portugal), they are included in my final sample since they were in part of the sample period deemed emerging. The final sample is outlined in Table 1.

In Table 1, I outline by country, the first year in which firms enter the database, the number of firms (No. of Obs) and the number of firm-year observations. Since Worldscope coverage of emerging market firms is sparse in the 1980s, much of the firms in my final sample do not enter until the middle part of the sample period. For example, firms (which pass the data requirements) from Argentina, Brazil, Philippines, Taiwan and Turkey do not enter the sample until 1990, while firms from amongst others, Chile (1992), China (1992), and Pakistan (1994), enter later. The early part of the sample period is entirely comprised of firms from Korea, Malaysia, Mexico and South Africa. Firms from these countries enter the sample in 1982. The number of sample firms per country varies from a high of $547(2,553$ firm-year observations) from Korea, to a low of just 10 firms for Colombia (81 firm-year observations). Malaysia (307 firms), Taiwan (256 firms), India (227) and South Africa (215) collectively supply 1,005 firms (6,188 firm-year observations) to the final sample of firms.

To measure financial liberalisation, I use the financial liberalisation index constructed by Abiad et al. (2008). This index tracks several dimensions of financial sector reforms in 60 countries from 1973 to 2002. These are (i) credit controls and reserve requirements; (ii) interest rate controls; (iii) bank entry barriers; (iv) bank privatisation; (v) bank supervision; (vi) security market reforms and (vii) international capital flows. Along each of the seven dimensions, a country is given a score on a graded scale from 0 to 3. Zero refers to the highest degree of repression and three refers to fully liberalised. Consequently, a higher score indicates a higher degree of 


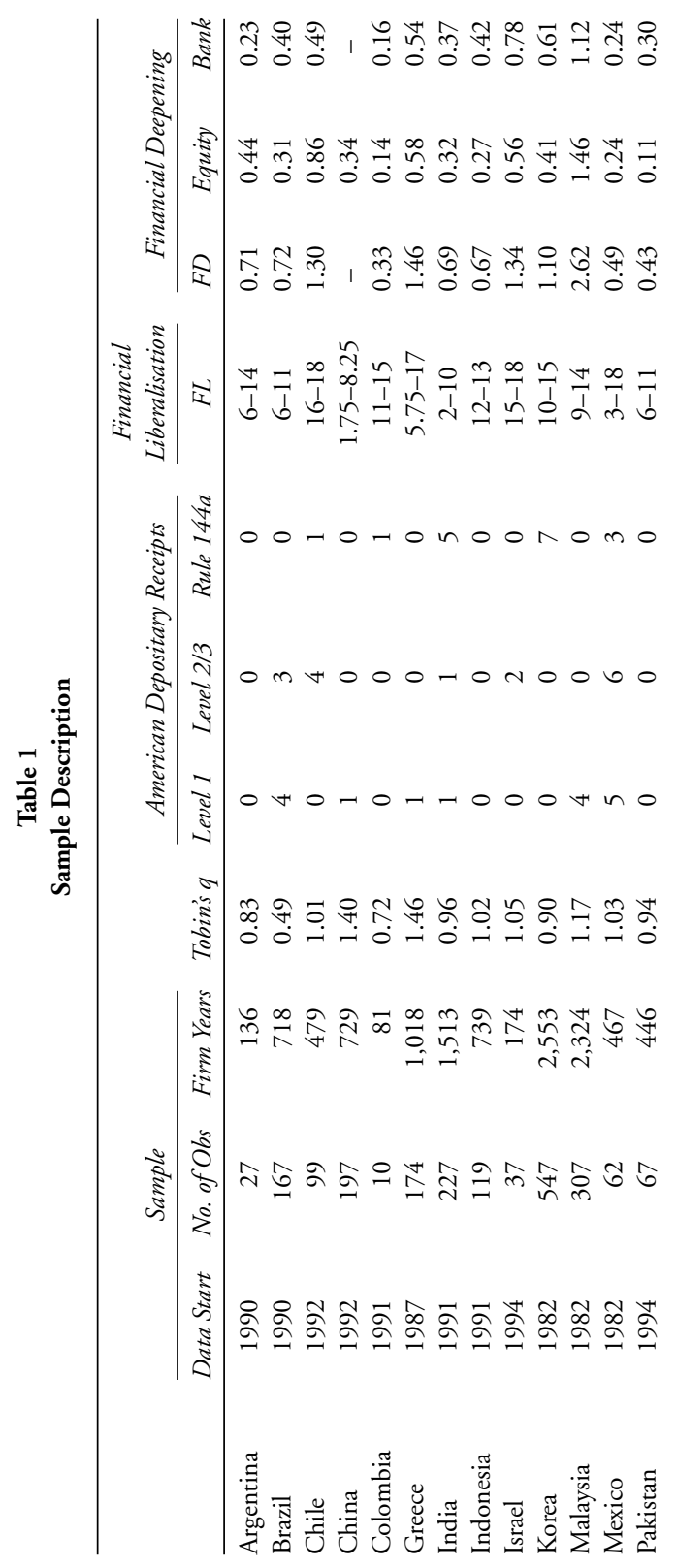




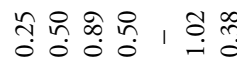

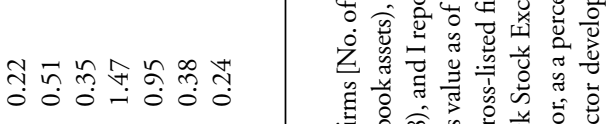

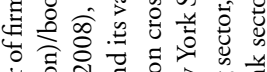

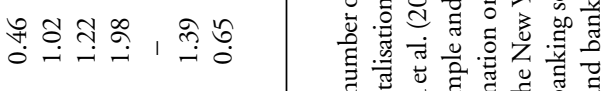

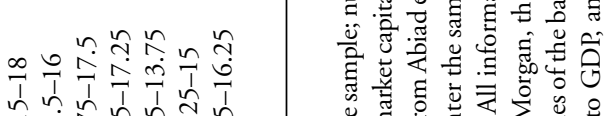

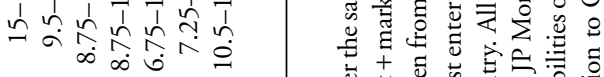

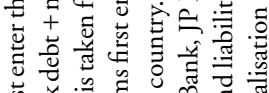

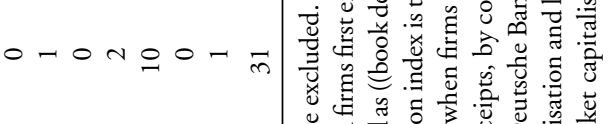

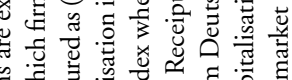

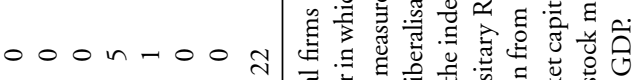



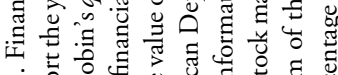

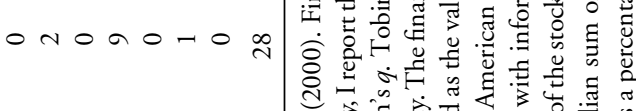

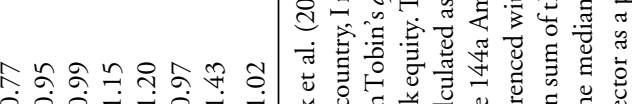

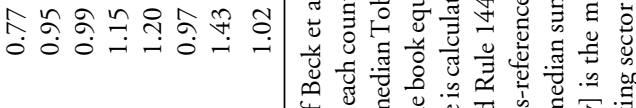

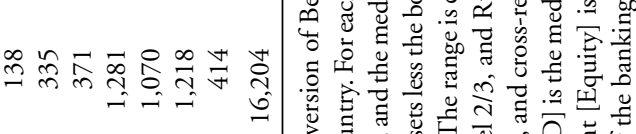

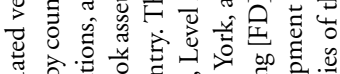

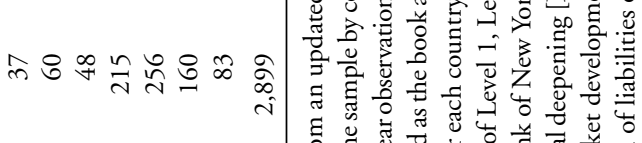

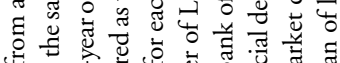

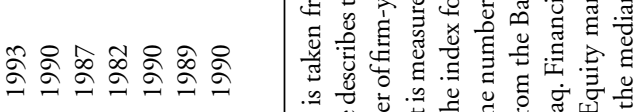

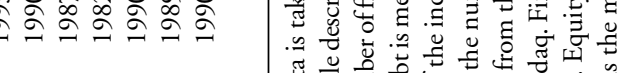

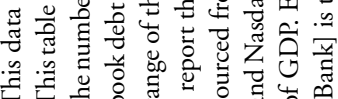

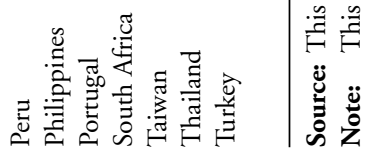


financial liberalisation. The authors identified the various policy changes by consulting a number of different sources. These included surveys of financial liberalisation, central bank bulletins and websites, IMF country reports, books and other journal articles. The combined index ranges from a low of 0 to a high of 18 if the country is fully liberalised. In Figure 1, I outline the median value and trend of the financial liberalisation index from 1982 to 2002. The trend is calculated as the coefficient estimates on the year dummies (relative to 1982) from estimating the following regression: $F L_{c t}=\alpha+$ Country $_{c}+$ Year $_{t}+$ $\varepsilon_{\mathrm{it}}$, where FL is the financial liberalisation index, Country and Year are country and year fixed effects, respectively. I include the trend variable since financial liberalisation data coverage differs across countries, and thus changes in median value are likely to be, in part, influenced by changes in sample composition (from countries entering the sample at different times). The median and trend data show how emerging financial markets have become more liberalised over time. For each country, I report the range of the financial liberalisation index, which I define as the range of values that the index

Figure 1

Financial Development

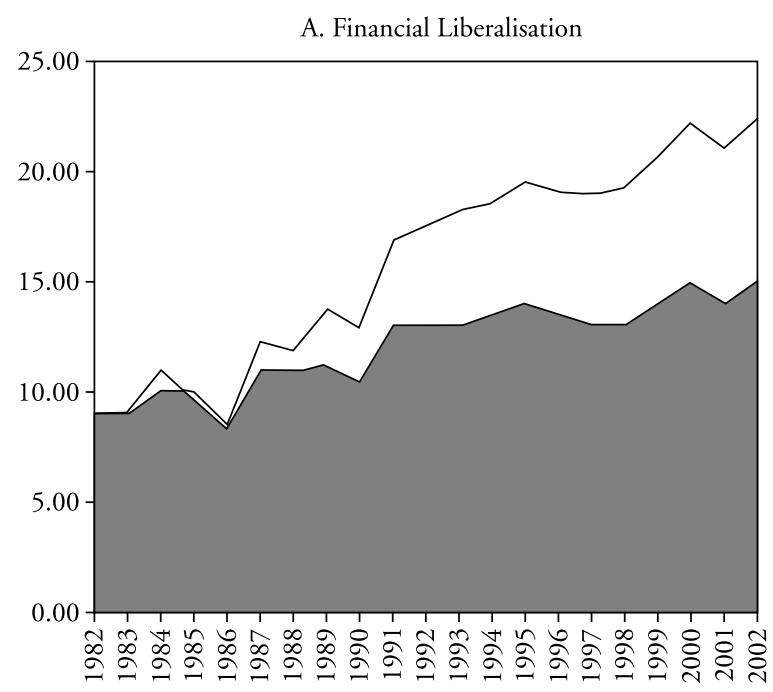

$\square$ Median $\square$ Trend

(Figure 1 continued)

Journal of Emerging Market Finance, 10:1 (2011): 21-71 
Financial Development, Internationalisation and Firm Value / 31

(Figure 1 continued)

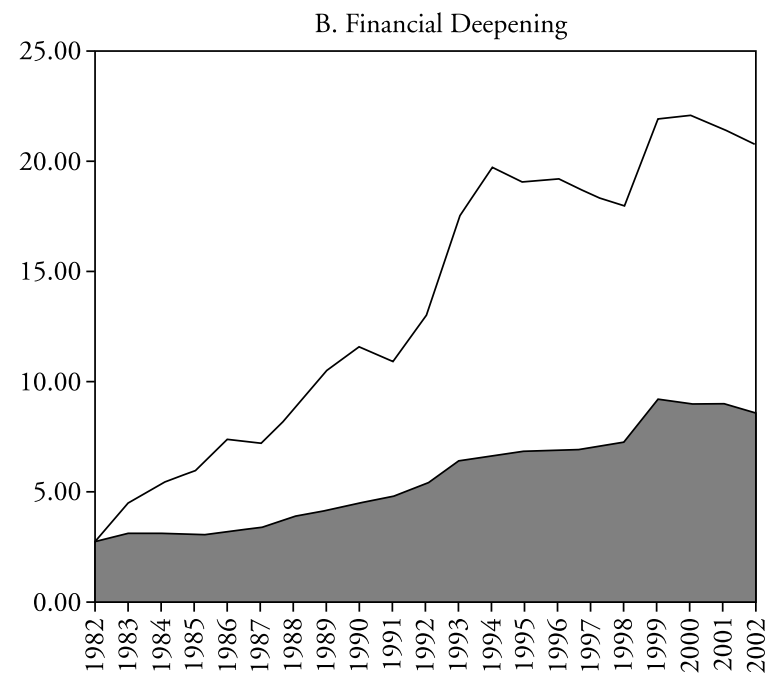

$\square$ Median $\square$ Trend

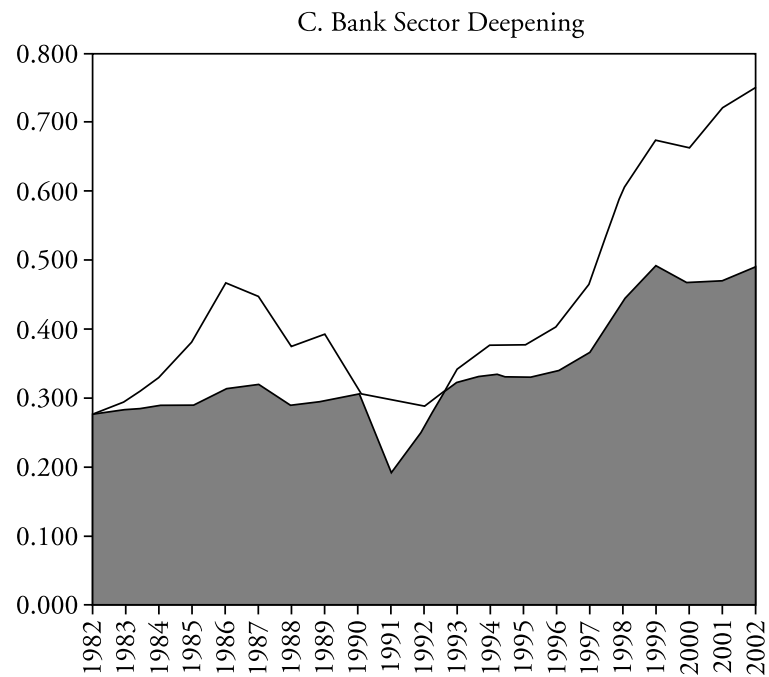

$\square$ Median $\square$ Trend

(Figure 1 continued)

Journal of Emerging Market Finance, 10:1 (2011): 21-71 
(Figure 1 continued)

D. Equity Market Deepening

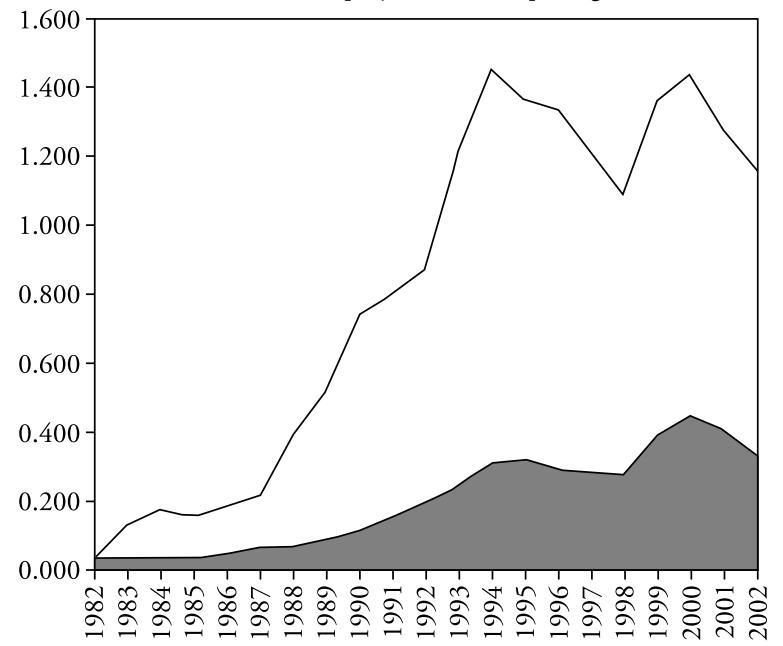

$\square$ Median $\square$ Trend

\begin{tabular}{lcccc}
\hline & $\begin{array}{c}\text { Financial } \\
\text { Liberalisation }\end{array}$ & $\begin{array}{c}\text { Financial } \\
\text { Deepening }\end{array}$ & $\begin{array}{c}\text { Equity } \\
\text { Deepening }\end{array}$ & $\begin{array}{c}\text { Bank } \\
\text { Deepening }\end{array}$ \\
\hline Mean & 13.15 & 1.28 & 0.68 & 0.61 \\
Median & 14.00 & 1.10 & 0.41 & 0.50 \\
Standard deviation & 3.14 & 0.78 & 0.57 & 0.29 \\
\hline
\end{tabular}

Source: Financial deepening data is sourced from an updated version of Beck et al. (2000).

Notes: This figure displays the median and trend (within-country) for measures of financial liberalisation, financial deepening, equity (stock), and bank sector deepening from 1982 to 2002. The index of financial liberalisation ranges from 0 to 18 (fully liberalised) and is taken from Abiad et al. (2008). Financial deepening is the sum of stock and bank sector deepening. Equity/stock market deepening is measured as stock market capitalisation to GDP, and bank sector deepening is measured as liabilities of the banking sector, also as a percentage of GDP.

takes from the time in which firms from each country first enter the sample (see Column 2) to the end of the sample period (2002). Since reversals are possible in the Abiad et al. (2008) index, the range does not necessarily correspond to the difference between the minimum and maximum values. Over the sample period, Chile, Israel, Mexico and Peru became fully liberalised

Journal of Emerging Market Finance, 10:1 (2011): 21-71 
(all have a maximum value of 18), China remained the least liberalised (8.25), and Mexico experienced the greatest improvement in financial sector reforms.

To measure financial deepening, I follow Schmukler and Vesperoni (2006), and use the sum of stock and bank sector deepening. Stock market deepening is measured as stock market capitalisation to GDP, and bank sector deepening is measured as liabilities of the banking sector, also as a percentage of GDP. This data is sourced from an updated version of the financial development database provided by Beck et al. (2000). In the last three columns of Table 1, I outline the median value (measured over time) of each of the financial deepening measures by country. Bank sector deepening data is unavailable for both China and Taiwan. Equity markets tend to be larger in Malaysia, South Africa and Taiwan, and in the case of Malaysia and South Africa, as a percentage of GDP, equity markets tend to be larger than the banking sector. In contrast, as a percentage of GDP, the banking sector is, relative to the equity market, larger in Israel, Pakistan, Portugal and Thailand. On an absolute basis, the banking sector is more highly developed in Malaysia, Thailand, Portugal and Israel. Over the sample period, Malaysia witnessed the greatest equity and bank sector deepening (unreported). In contrast, Pakistan experienced the least. Figure 1 displays the median and trend of each of these financial deepening variables over time. These suggest that the banking sector and equity markets have become highly developed over time.

Finally, I use US cross-listings to proxy for firm-level globalisation/internationalisation. Gozzi et al. (2008) classify firms as international firms if they are either cross-listed in the US, or raise capital internationally. Schmukler and Vesperoni (2006) do likewise. I do not have access to international capital-raising data, and as such, I only use US cross-listing ADRs to classify firms as international. There are four different types of ADRs, namely, Level 1, Level, 2, Level 3, and Rule 144a. Levels 2 and 3 are traded on the New York Stock Exchange (NYSE), the National Association of Securities Dealers Automated Quotation System (NASDAQ), and the American Stock Exchange (AMEX). Most foreign firms that use ADRs typically do so on either the NYSE or Nasdaq. The vast majority of foreign firms on the AMEX are ordinary Canadian lists. Level 1 firms trade over-the-counter (OTC), and Rule 144a ADRs are privately placed to Qualified Institutional Buyers (QIB) on Portal. The disclosure and regulatory requirements of international firms that list in the US differ across the different listing choices. Firms that list as 
ordinary shares, e.g., mainly Canadian and Israel firms, or as Level 2/3 ADRs on US exchanges, i.e., NYSE, AMEX, Nasdaq, are mandated to provide greater disclosures and reconcile their accounting procedures to US GAAP. These firms are subject to both the oversight of the Securities and Exchange Commission, and the same Securities Laws that bound native US firms, e.g., they are subject to civil liability under Section 18 of the 1934 Securities \& Exchange Act. These firms are also subject to the listing requirements and governance obligations of the individual exchanges, although these can be waived in certain instances. Finally, the Sarbanes-Oxley Act of 2002 requires that CEO's and CFO's must personally certify that information in each year filed under form $20-\mathrm{F}$ is accurate and free from material misstatements and omissions, and that the financial statements and other financial information in the report fairly present, in all material respects, the issuer's financial position, results of operations and cash flows. In contrast, firms that trade in the US as Level 1 and/or Rule 144a lists are subject to minimal listing and regulatory requirements. Both are exempt from reconciling their accounts to US GAAP, and are minimally affected by the Sarbanes-Oxley Act. They require minimal SEC registration and are exempt from the SEC's reporting and accounting obligations under Rule 12g3-2(b). They provide instead, an English translation of financial statements prepared according to home country accounting practices.

All information on cross-listed firms is sourced from the Bank of New York, and cross-referenced with information from Deutsche Bank, JP Morgan, the New York Stock Exchange and Nasdaq. I classify firms according to their initial cross-listing in the US and ignore all subsequent listings changes, e.g., upgrades from Level 1 over-the-counter to Level 2/3 exchange traded depositary receipts. I take great care to identify a firm's initial listing. To do so, I consult the historical records from the Bank of New York (since the currently available online records refer to a firms current [and not previous/ initial] cross-listing). I cross-reference this data with the cross-listing database provided by Citibank. Specifically, they flag firms that have changed their cross-listing status by including a 'successor depositary receipt' data type for all firms. Using both databases, firms are classified as either a Level 1 overthe-counter, Level 2/3 exchange-traded, or a Rule 144a listing that trade on Portal to Qualified Institutional Buyers.

I employ Tobin's $q$ to measure firm value, where Tobin's $q$ is defined as the book debt plus market capitalisation divided by the book assets. Similar to Gozzi et al. (2008), I ultimately deviate away from the original definition of 
Tobin's $q$ by proxying for market debt by using its book value counterpart, and measure the replacement cost of assets as book assets. Book debt is calculated as book total assets less book equity. Doidge et al. (2004, 2009), Gozzi et al. (2008), and Mitton and O'Connor (2010) also use Tobin's $q$ to proxy for firm value in their studies on the valuation effects of international cross-listings, internationalisation and investability, respectively. All firmlevel financial information is sourced from Worldscope for each year from 1982 to 2002. In the fifth column of Table 1, I outline the median Tobin's $q$ by country. These figures are generally in line with Chua et al. (2006): the median Taiwanese (Tobin's $q$ of 1.20) and Chinese (Tobin's $q$ of 1.40) firms tend to be worth more than other emerging market firms. ${ }^{9}$

I control for firm- and industry-related factors commonly employed in other studies using Tobin's $q$. I use the average (geometric) sales growth (inflation-adjusted) over the last two years and global industry $q$ to account for firm and industry growth, respectively. On the basis of the Worldscope General Industry Classifications, the (yearly) mean global industry $q$ is calculated as the average $q$ of all global firms within each classification. I use the $\log$ of sales (inflation-adjusted and in US\$), rather than total assets (given the definition of Tobin's $q$ ) to control for firm size.

\section{Methodology and Results}

To examine the relationship between financial liberalisation, deepening, internationalisation and firm value, I estimate within-firm regressions of the following form:

$$
\begin{aligned}
q_{i, t}= & \alpha+\beta_{1} X_{i, t}+\gamma_{1} \text { FinLib }_{c, t}+\gamma_{2} \text { FinDeep }_{c, t}+\gamma_{3} \mathrm{~L}_{i, t} \\
& +\gamma_{4} \mathrm{~L}_{2} / 3_{i, t}+\gamma_{5} \text { Rulel444a }_{i, t}+\text { Year }_{t}+\text { Firm }_{i}+\mathrm{e}_{i, t}
\end{aligned}
$$

where $q$ is Tobin's $q, X_{i t}$ is a set of firm-level controls (i.e., firm growth, firm size, and global industry q); FinLib is financial liberalisation, L1, L2/3, and Rule 144a are dummy variable that equals 1 if firm $i$ cross-lists in the US either as a Level 1, Level $2 / 3$, or Rule 144a ADR in year $t$ and zero otherwise, FinDeep is financial deepening, Year $_{t}$ represents a full set of year dummy

${ }^{9}$ Interestingly since 1993, the value of emerging market firms has tended to fall. By the end of 2002, emerging market firms were worth considerably less than they were at the start of the sample period (i.e., a within-firm trend fall of 0.30 between 1982 and 2002), which is economically large since the average firm has a Tobin's $q$ of 1.32 . 
variables and Firm $_{i}$ is a full-set of firm fixed effects. The coefficient estimates that results from estimating variants of Equation (1) are presented in Table 2, with heteroscedastic-consistent $t$-statistics à la White (1980) presented underneath in brackets. ${ }^{10}$

In Column 1, I regress Tobin's $q$ on the financial liberalisation index alone. In the next three columns, I sequentially add firm-level control variables in turn. Column 5 contains the coefficient estimates, which result from including financial liberalisation and internationalisation (i.e., equity cross-listings) simultaneously. In Column 6, I maintain the cross-listing variables, but replace the financial liberalisation index with the financial deepening measure. In Column 7, I include all three measures simultaneously. In Columns 8 and 9, I include both components of financial deepening individually, along with the financial liberalisation and internationalisation dummies. Finally, in Column 10, both equity and bank sector deepening, along with financial liberalisation and the cross-listing dummies are included simultaneously.

The coefficient estimates suggest the following: First, in Columns 1 to 4, the financial liberalisation index is positive and statistically different from 0 . The coefficient estimates range from 0.016 to 0.024 , which suggests that financial liberalisation has a positive impact on firm value. Furthermore, in all specifications, the firm-level controls are statistically significant, and are of the correct sign: firm value increases in firm and industry-level growth and larger firms tend to be worth less. These results are consistent with the findings of Laeven (2003) and Love (2003) who find that financial liberalisation reduces firm-level financing constraints. Column 5 is Column 4, but now with crosslisting dummy variables included. Like others, I find that Level 2/3 firms enjoy the largest cross-listing premium (see Doidge et al. 2004, 2009), although I document much smaller, and even negative listing premia for both Level 1 and Rule 144a issues. Also, financial liberalisation remains statistically (and economically) significant even, given the inclusion of the cross-listing dummy variables. Thus far the results suggest that financial liberalisation and a Level $2 / 3$ cross-listing in the US impact positively on firm value.

In Column 6, I take a first look at how financial deepening impacts on firm value. Here, I regress Tobin's $q$ on financial deepening, firm-level controls and

\footnotetext{
${ }^{10}$ To try and alleviate any concerns regarding endogeneity, I re-estimate Equation (1) but now with lagged values of the financial liberalisation and deepening variables. The conclusions remain the same.
}

Journal of Emerging Market Finance, 10:1 (2011): 21-71 


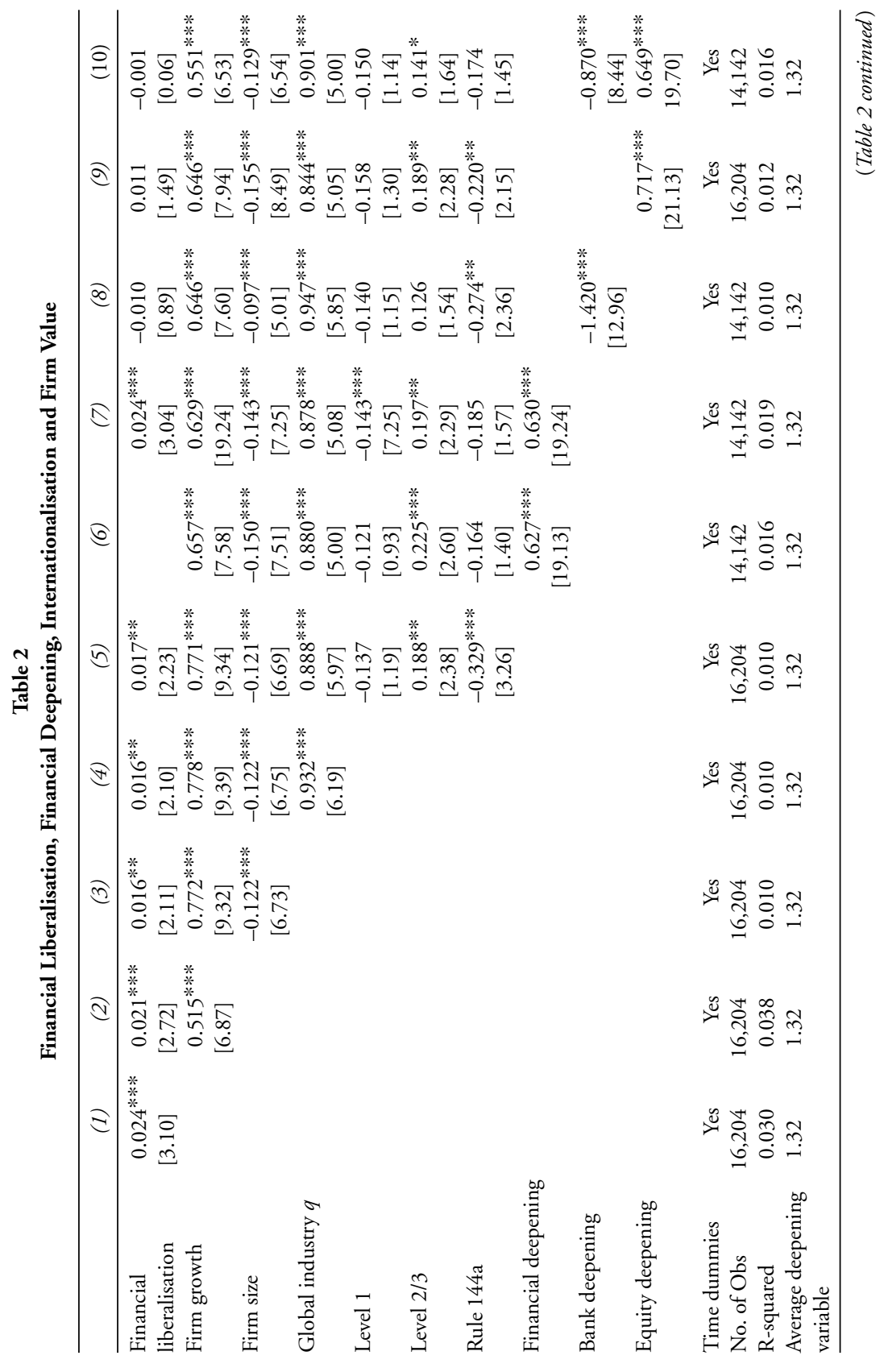




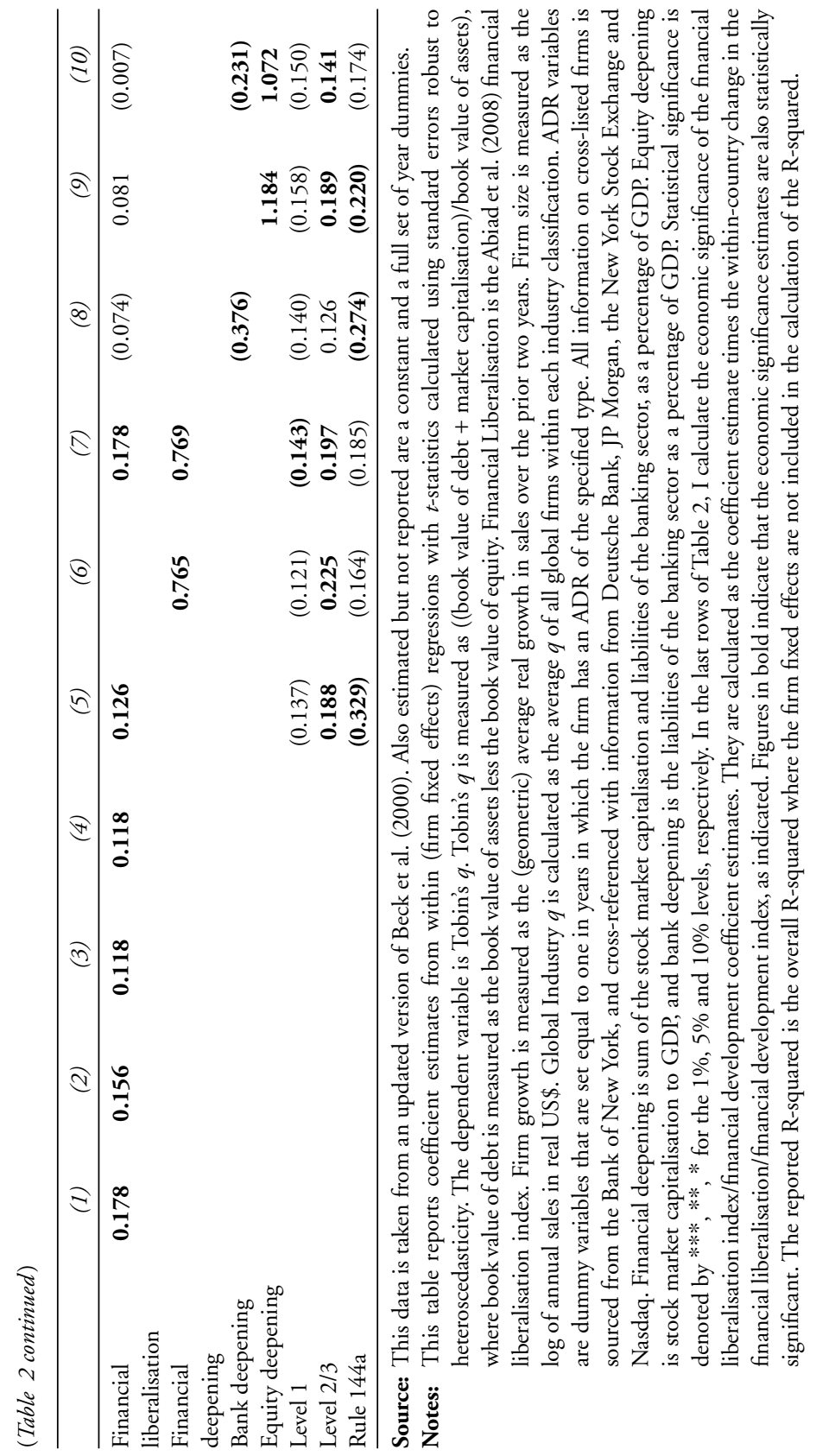


the cross-listing dummy variables. In Column 7, I add the financial liberalisation index to this specification. Taken together, both financial liberalisation and financial deepening impact positively on firm value. The coefficient estimates on the financial deepening variable is positive and statistically significant in both Columns 6 and 7. Furthermore, adding the financial deepening measure to Column 5 (presented in Column 7) does not reduce the statistical significance on the coefficient of the financial liberalisation index. Finally, even given the inclusion of the financial development indicators, Level 2/3 firms still enjoy the largest cross-listing premium. In Columns 8 and 9, I separate financial deepening into its constituent parts, and estimate how they impact individually on firm value. In Column 10, I include these variables simultaneously, along with the financial liberalisation index, the crosslisting dummies, and the full collection of firm- and industry-level controls. Interestingly, the financial deepening components impact very differently on firm value. Firm value increases in equity market development. In stark contrast, bank sector deepening impacts negatively on firm value. Second, financial liberalisation is no longer statistically significant once I include the components of financial development separately. Again a Level 2/3 exchange traded ADR impacts positively on firm value, even allowing for the fact that the financial development measures enter individually. Taken together, these results suggest that firms only accrue value from equity market development and exchange cross-listings in the US. Financial liberalisation is no longer significant once bank and equity deepening are included individually.

Next I assess the economic significance of the coefficient estimates just presented. The coefficient estimates from Columns 7 and 10 of Table 2 suggest that the greatest gains arise from financial deepening, or more precisely, equity market deepening. For example, a one standard deviation increase in financial liberalisation (of 3.14 which is similar to the range of financial liberalisation experienced in Colombia over the sample period) implies an increase in Tobin's $q$ of 0.075 , which is about 5.68 per cent of the average value of the firms in the sample. Going from the highest to the lowest values of financial liberalisation (i.e., 0 to 18) implies an increase in Tobin's $q$ of 0.43 , which is 32.57 per cent of the average firm value in the sample. In Mexico, where the most widespread liberalisation reforms occurred over the sample period, the implied change in value for Mexican firms was 0.36 , or 34.95 per cent of the median value of Mexican firms.

The gains from financial deepening are greater. A one standard deviation in financial deepening (of 0.78 which is almost identical to the range of financial 
deepening experienced in the Philippines and South Africa over the sample period) is associated with a change in Tobin's $q$ of 0.49 , which is 37.12 per cent of the average firm value. These gains arise from equity market deepening, and not bank sector deepening. A one standard deviation increase in equity market deepening (of 0.57 which is similar to the range of equity market deepening experienced in Taiwan) implies an increase in Tobin's $q$ of 0.37 . In contrast, the same one standard deviation change in bank sector deepening (of 0.29 which is the range of bank sector deepening in the Philippines) implies a decrease in value of 0.25 , or 18.94 per cent of average firm value. Finally, the gains from internationalisation are lower. The largest implied change in firm value arising from a Level $2 / 3$ listing in the US is 0.225 , which is less than the gains from financial deepening and financial liberalisation, but they do compare more favourably with the gains from the latter. In summary, the greatest valuation gains arise from financial deepening, or more precisely, equity market deepening, then financial liberalisation, and finally financial internationalisation. Bank sector deepening leads to lower firm value.

Finally, I assess the economic significance over the sample period of the results just presented in Table 2. I estimate their economic significance, in order to gauge the importance of each, both on an absolute basis and relative to each other. Mitton and O'Connor (2010) and Doidge et al. (2004, 2009) find that investability (a firm-level measure of stock market liberalisations) and cross-listings in the US are value enhancing, respectively. In this article, I try and examine which, namely, financial development (i.e., liberalisation and deepening) or financial internationalisations via cross-listings are more important. To assess their economic significance, I estimate how changes in these country- and firm-level factors between 1982 and 2002 may have impacted on firm value over this period based on the coefficient estimates presented in Table 2. The economic significance estimates are calculated as the within-country trend in either financial liberalisation or financial deepening over time times the coefficient estimates on each of the main variables, i.e., financial liberalisation, financial deepening, equity and bank deepening. The within-country trends for the country-level financial development indicators are derived from the following country-fixed-effects regression: $\left(\mathrm{FD}_{c t}=\alpha+\right.$ Country ${ }_{c}+$ Year $_{t}=\varepsilon_{c t}$ ), where FD is either financial liberalisation or financial deepening, Country ${ }_{c}$ are country-fixed-effects and Year $_{t}$ are a full-set of yearfixed-effects (where 1982 is the reference year). Since the cross-listing dummy variables are simple $0 / 1$ dummies, their economic significance is calculated as one times the coefficient estimate on each of the dummies, respectively. 
In the bottom panel of Table 2, I outline the estimates of the effects of each financial sector reform on firm value. Estimates in bold signify that the coefficient estimates presented in the top panel of Table 2 are statistically significant at conventional levels.

The within-country trend in financial liberalisation and financial deepening over the period from 1982 to 2002 is 7.41 and 1.22 , respectively. The corresponding trends for equity and bank sector development are 0.833 and 0.261 , respectively. The increase in financial liberalisation (in Columns 1 to 8 of Table 2) implies an average increase in the value of firms ranging from 0.118 to 0.178 . Since the average emerging market firm has a Tobin's $q$ of 1.32 (calculated over the entire sample period), this implies an increase in value ranging from 8.98 to 13.45 per cent. The corresponding increase in financial deepening implies an even lager increase in firm value ranging from 0.765 to 0.769 , which is just under 60 per cent of the value of the average firm in the sample. Equity market deepening over the sample period implies an average increase of 1.128 , compared to an average decrease in value of 0.304 for bank sector deepening. Similar to others (Doidge et al. 2004, 2009; O'Connor 2009b), I find a cross-listing premium for Level $2 / 3$ lists, but unlike others, not for Level 1/Rule 144a issues. Furthermore, the coefficient estimate on the Level $2 / 3$ dummies suggests that these firms enjoy a larger cross-listing premium relative to the premium documented by Doidge et al. (2009). Specifically, an exchange-traded Level $2 / 3$ issue leads to a withinfirm change in value ranging from 0.126 to 0.225 (compared to Doidge et al., 2009, coefficient estimates of 0.08 to 0.16 ). This implies an increase in value ranging from 9.54 to 17.05 per cent, respectively. ${ }^{11}$

In the last column of Table 2, I include all of the variables in a single regression and present estimates of their economic significance. Like before, only equity market deepening and financial internationalisation via a Level 2/3 ADR impact positively on firm value. Using Column 10, the economic significance of the equity market development (deepening) variable is 7.65 times the estimate on the Level $2 / 3$ cross-listing dummy (i.e., 1.072/0.141). Finally, on the basis of the coefficients estimates presented in Table 2, a Level $2 / 3$ cross-listing creates more value for firms than financial liberalisation over the sample period, although the difference is not very large. This contrasts with earlier findings, since at the beginning of

\footnotetext{
${ }^{11}$ Of course, the results are not directly comparable to Doidge et al. (2009) since their study combines developed and emerging market firms.
} 
the sample period, many countries had already well advanced their financial liberalisation programmes. The results from earlier findings would then suggest that over an extended period, which includes the period that predates this sample period, financial liberalisation creates more value than financial internationalisation for emerging market firms.

In summary, the results suggest that the greatest gains from financial sector reforms arise from stock market deepening. Typically, financial liberalisation delivers more value than financial internationalisation, although over the sample period, they both deliver about the same valuation gains. ${ }^{12}$ Finally, bank sector deepening only serves to reduce firm value.

\subsection{The components of financial liberalisation}

The previous section suggests that financial liberalisation enhances firm value. In Table 3, I disaggregate the financial liberalisation index into its constituent parts and estimate how each, in turn, and then collectively, impact on firm value. In this specification, multicollinearity may be an issue since the reforms essentially take place at the same time. In turn, this may serve to lower the significance of the individual coefficient estimates. Table 3 contains coefficient estimates from 13 separate regressions: in the first seven, I regress Tobin's $q$ on each of the seven component parts of the financial liberalisation index. In Column 8, all variables are included together. Column 9 contains the coefficient estimate on the financial deepening variable, and in Column 10, I augment this specification with the individual financial liberalisation variables. In Columns 11-13, I include all of the financial liberalisation variables with the individual financial deepening measures. For the sake of brevity, I will concentrate on outlining the results from Column 8 and Columns 11-13. Again, estimates of the economic significance over

\footnotetext{
${ }^{12}$ While I do not include cross-listings in London in this article, the most recent research suggests that at best, cross-listing premia in London are of the same magnitude of those experienced by firms that list as Level 2/3 ADRs in the US. Bianconi and Tan (2010) find evidence to support this, while Doidge et al. (2009) disagree and find that cross-listing in London does not manifest into a cross-listing premium for these firms. Doidge et al. (2009) do not include Alternative Investment Market (AIM) traded firms in their sample. O'Connor (2009a) does and finds that AIM listed Irish firms enjoy the largest cross-listing premia of all cross-listed Irish firms, which is inconsistent with the predictions of the bonding hypothesis.
}

Journal of Emerging Market Finance, 10:1 (2011): 21-71 
the sample period of each reform measure are presented in the remaining rows of Table $3 .^{13}$

The coefficient estimates from Column 8 suggest that firm value increases with interest rate reforms, a reduction in entry barriers and with greater international capital flows. The latter is consistent with Harrison et al. (2004) and Forbes (2007) who find that greater capital controls only serves to increase firm-financial constraints. In the case of Chile, Forbes (2007) finds that the increase in financial constraints was greatest for small- and mid-size firms. Furthermore, recent findings of Giannetti and Ongena (2009) suggest that foreign bank entry has important positive implications for non-financial firms, notably small firms, but adverse effects for well-connected (i.e., bank or government) domestic firms. ${ }^{14}$ Specifically, they show that foreign bank entry (in emerging markets) is associated with growth in firm sales, assets and leverage, where the latter benefit is especially important given the underdevelopment of equity markets in these countries (Booth et al. 2001; Giannetti 2003). ${ }^{15}$

In contrast, security market reforms and privatisation of the banking sector destroy value. These results also manifest once I control for financial deepening (see Column 10), but as before, financial deepening contributes much more to firm value than any of the individual financial liberalisation variables. The results for security market reforms are in contrast with others (Henry 2000; Mitton 2006; Mitton and O'Connor 2010) who all associate

\footnotetext{
${ }^{13}$ Along similar lines, Bebchuk et al. (2009) demonstrate that not all of the governance provisions employed in the G-Index of Gompers et al. (2003) impact firm value.

${ }^{14}$ Laeven (2001) reaches similar conclusions. He finds that foreign bank entry facilitates greater lending to young firms, who are financially constrained since they are not well connected. In turn, foreign banks have few connections to local families. Furthermore, foreign bank entry also facilitates greater competition in the banking sector, which should benefit most firms. Claessens and Laeven (2004) show that competition in the banking sector is greatest in systems with greater foreign bank entry.

${ }^{15}$ However, there are instances where foreign bank entry is not always beneficial. For example, in the case of foreign bank entry in India, Gormley (2010) finds that foreign bank entry only serves to increase, rather than reduce information asymmetries, resulting in 'cream skimming, i.e., banks lend only to a small group of large firms (which are likely to be less financially constrained than smaller firms), since the cost of information retrieval is large. Beck et al. (2009) also find evidence of 'cream skimming/cherry-picking' in Mexico following foreign bank entry. They also show that the mode of entry was via acquisitions of foreign banks as opposed to de novo bank entry.
} 


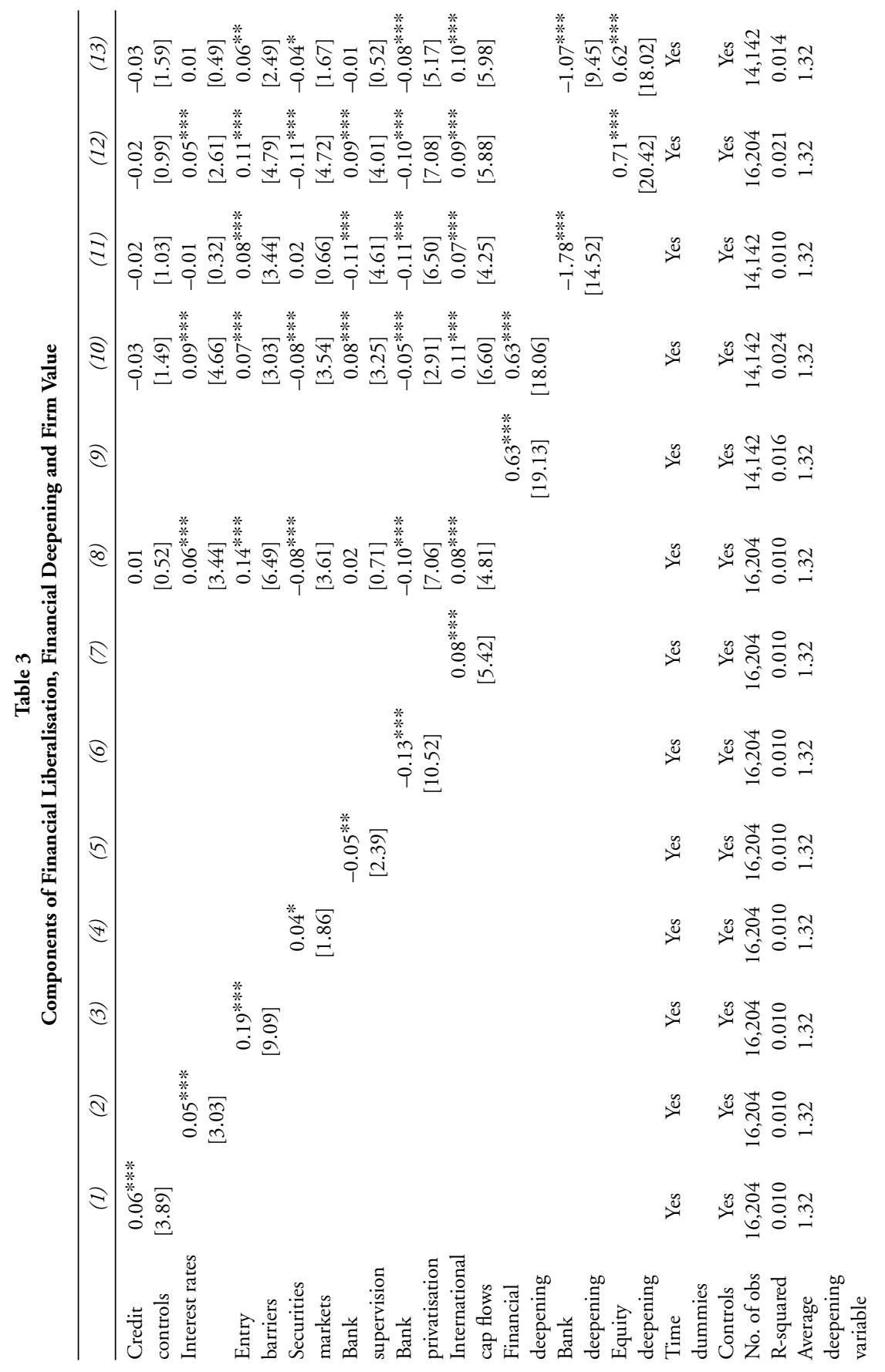




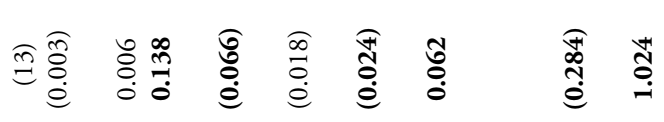

现営

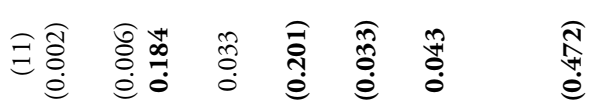

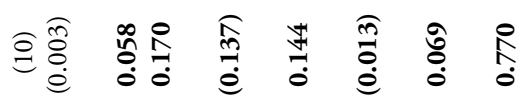

$\widehat{\sigma}$

กัฒ

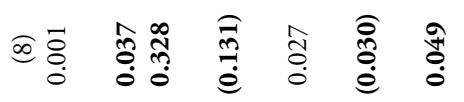

\&

(6)

$\stackrel{\widehat{\infty}}{\stackrel{0}{e}}$

$\sqrt{2}$

$\widehat{\infty}$
$\stackrel{0}{0}$
$\stackrel{e}{0}$

ङ $\quad \stackrel{0}{0}$

त)

ลิ

Ð

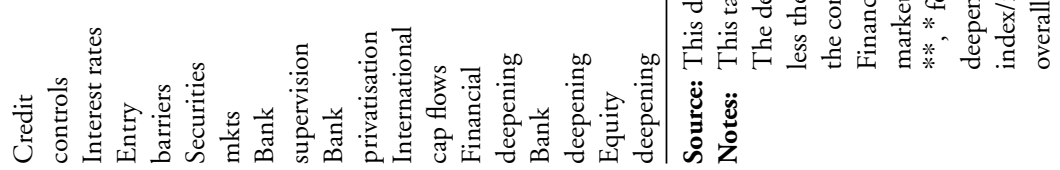


stock market liberalisation with positive outcomes for firms. Furthermore, a large literature also shows that privatisation of the banking sector is generally beneficial since state ownership of banks is associated with less access to credit, reduced financial stability and lower economic growth (Berger et al. 2004; Ceterolli 2001). ${ }^{16}$ Finally, I find mixed results when I examine how banking supervision affects firm value.

Similar to Table 2, the coefficient estimate on the financial deepening variable in Column 10 implies a within-firm appreciation in Tobin's $q$ in the region of 0.77 over the entire sample period. The implied change in firm value from interest rate reforms, a reduction in entry barriers, enhanced bank supervision and greater international capital flows are 0.058, 0.170 and 0.069 , respectively. Their effect on firm value is much lower, both individually and collectively (0.297) than the change implied by financial deepening. Interestingly, the change in value implied by a reduction in entry barriers is similar to the change derived from listing in the US as a Level 2/3 exchange-traded depositary receipt (see Table 2 for the relevant figures). In contrast, while security market reforms and bank privatisation lower firm value, security market reforms cause much greater falls in firm value. The economic significance estimates from Table 3 suggest that security market reforms over the sample period imply a fall in value of 0.137 , compared to a fall of just 0.013 for enhanced bank privatisation. Finally, while not reported, the control variables are again correctly signed, and statistically significant.

In Columns 11-13, I include the components of financial deepening with the individual components of the financial liberalisation index. By and large, the coefficient estimates and their level of statistical significance are maintained once I include the financial deepening variables individually. As before, firm value increases with a reduction in entry barriers, interest rate deregulation and greater international capital flows, while value decreases in security (equity) market reforms and greater privatisation of the banking sector. Consistent with Table 2, equity (bank) sector deepening increases (decreases) firm value. Finally, security (equity) market reforms and equity market development impact differently on firm value, while bank privatisation and bank sector deepening decrease firm value. Collectively, financial deepening implies an average increase in Tobin's $q$ of 0.768 (1.099 for equity

\footnotetext{
${ }^{16}$ A related literature demonstrates how privately owned banks perform better than stateowned (Cornett et al. 2010).
}

Journal of Emerging Market Finance, 10:1 (2011): 21-71 
market deepening and -0.378 for bank sector deepening). A reduction in entry barriers implies an average change in value of 0.186 over the sample period, while the change in value implied from an increase in international capital flows is lower at 0.058 . Compared to Table 2 , the change in value implied by a reduction in entry barriers is similar to the valuation gains from cross-listing on US exchanges.

The results from Table 2 suggest that on the whole, financial liberalisation and equity deepening enhance value, while bank sector deepening only serves to reduce value. Of course, it remains possible that in the case of the former, increased value does not materialise immediately (i.e., at low levels of financial liberalisation), and in the case of the latter, enhanced bank deepening is not always associated with lower value. To address these possibilities, I estimate the following:

$$
\begin{aligned}
q_{i, t}= & \alpha+\beta_{1} X_{i, t}+\gamma_{1} \text { FinLib }_{c, t}+\gamma_{2} \text { FinLib }_{c, t}^{2}+\gamma_{3} \text { FinDeep }_{c, t} \\
& +\gamma_{4} \text { FinDeep }_{c, t}^{2}+\text { Year }_{t}+\text { Firm }_{i}+e_{\mathrm{i}, t},
\end{aligned}
$$

where I include squared terms of each of the financial development variables to account for possible nonlinear effects of each of the variables on firm value. The results are outlined in Table 4. In Table 4, I estimate four separate regressions; one each using financial liberalisation, financial deepening, equity and bank sector deepening. I supplement this analysis by outlining in Figure 2, the predicted Tobin's $q$ against financial liberalisation, financial deepening, equity and bank sector deepening, respectively (with all other variables held at their respective means). Figure 2 and the coefficient estimates from Table 4 paint a much more informative picture of how financial development impacts on firm value. ${ }^{17}$

\footnotetext{
${ }^{17}$ In a similar exercise, I partition the original sample and re-estimate Equation (1) depending on whether financial liberalisation/deepening is above or below the (country) sample median at each point in time. The results are presented in Appendix 1 and are in line with the results presented in Table 4. Specifically, financial liberalisation only enhances value where financial liberalisation is already well advanced (the coefficient on the financial liberalisation variable is only significantly positive in the above-median sample). In contrast, firm value is more sensitive to financial/equity deepening at low levels of each, although in the case of both, the greatest absolute increase in value is experienced when financial/equity deepening is well-advanced (i.e., 0.667 versus 0.211 using financial deepening, and 0.426 versus 0.371 using equity deepening). Finally, bank sector deepening tends to decrease value, beyond a low initial level of bank sector deepening.
} 
48 / Thomas O’ConNor

Table 4

Financial Liberalisation, Financial Deepening and Firm Value

\begin{tabular}{|c|c|c|c|c|}
\hline & (1) & (2) & (3) & (4) \\
\hline Financial liberalisation & $\begin{array}{c}-0.050^{*} \\
{[1.95]}\end{array}$ & & & \\
\hline Financial liberalisation squared & $\begin{array}{l}0.003^{* * *} \\
{[2.97]}\end{array}$ & & & \\
\hline Financial deepening & & $\begin{array}{c}0.937^{* * *} \\
{[10.51]}\end{array}$ & & \\
\hline Financial deepening squared & & $\begin{array}{l}-0.071 \text { *** } \\
{[3.84]}\end{array}$ & & \\
\hline Equity deepening & & & $\begin{array}{l}1.279^{* * * *} \\
{[14.40]}\end{array}$ & \\
\hline Equity deepening squared & & & $\begin{array}{l}-0.188^{* * *} \\
{[7.42]}\end{array}$ & \\
\hline Bank deepening & & & & $\begin{array}{l}0.212^{* * * *} \\
{[0.91]}\end{array}$ \\
\hline Bank deepening squared & & & & $\begin{array}{c}-0.999^{* * *} \\
{[7.77]}\end{array}$ \\
\hline Firm growth & $\begin{array}{l}0.777^{* * *} \\
{[9.38]}\end{array}$ & $\begin{array}{l}0.672^{* * * *} \\
{[7.69]}\end{array}$ & $\begin{array}{l}0.683^{* * *} \\
{[8.23]}\end{array}$ & $\begin{array}{l}0.604^{* * * *} \\
{[7.03]}\end{array}$ \\
\hline Firm size & $\begin{array}{c}-0.121^{* * *} \\
{[6.64]}\end{array}$ & $\begin{array}{l}-0.152^{* * *} \\
{[7.58]}\end{array}$ & $\begin{array}{l}-0.169^{* * *} \\
{[9.05]}\end{array}$ & $\begin{array}{l}-0.090^{* * *} \\
{[4.57]}\end{array}$ \\
\hline Global industry $q$ & $\begin{array}{l}0.935^{* * *} \\
{[6.19]}\end{array}$ & $\begin{array}{l}0.939^{* * *} \\
{[5.26]}\end{array}$ & $\begin{array}{l}0.909^{* * *} \\
{[5.26]}\end{array}$ & $\begin{array}{l}0.989^{* * *} \\
{[6.07]}\end{array}$ \\
\hline Time dummies & Yes & Yes & Yes & Yes \\
\hline No. of obs & 16,204 & 14,142 & 16,032 & 14,314 \\
\hline R-squared & 0.010 & 0.010 & 0.010 & 0.010 \\
\hline
\end{tabular}

Source: This data is taken from an updated version of Beck et al. (2000).

Notes: This table reports coefficient estimates from within (firm fixed effects) regressions with $t$-statistics calculated using standard errors robust to heteroscedasticity. The dependent variable is Tobin's $q$. Financial liberalisation is the Abiad et al. (2008) financial liberalisation index. Financial deepening is sum of the stock market capitalisation and liabilities of the banking sector, as a percentage of GDP. Equity deepening is stock market capitalisation to GDP, and Bank deepening is the liabilities of the banking sector as a percentage of GDP. Firm growth is measured as the (geometric) average real growth in sales over the prior two years. Firm size is measured as the log of annual sales in real US\$. Global Industry $q$ is calculated as the average $q$ of all global firms within each industry classification. Also estimated but not reported are a constant and a full set of year dummies. Statistical significance is denoted by ***, **, * for the $1 \%, 5 \%$ and $10 \%$ levels, respectively. The reported R-squared is the overall $\mathrm{R}$-squared where the firm fixed effects are not included in the calculation of the R-squared.

Journal of Emerging Market Finance, 10:1 (2011): 21-71 


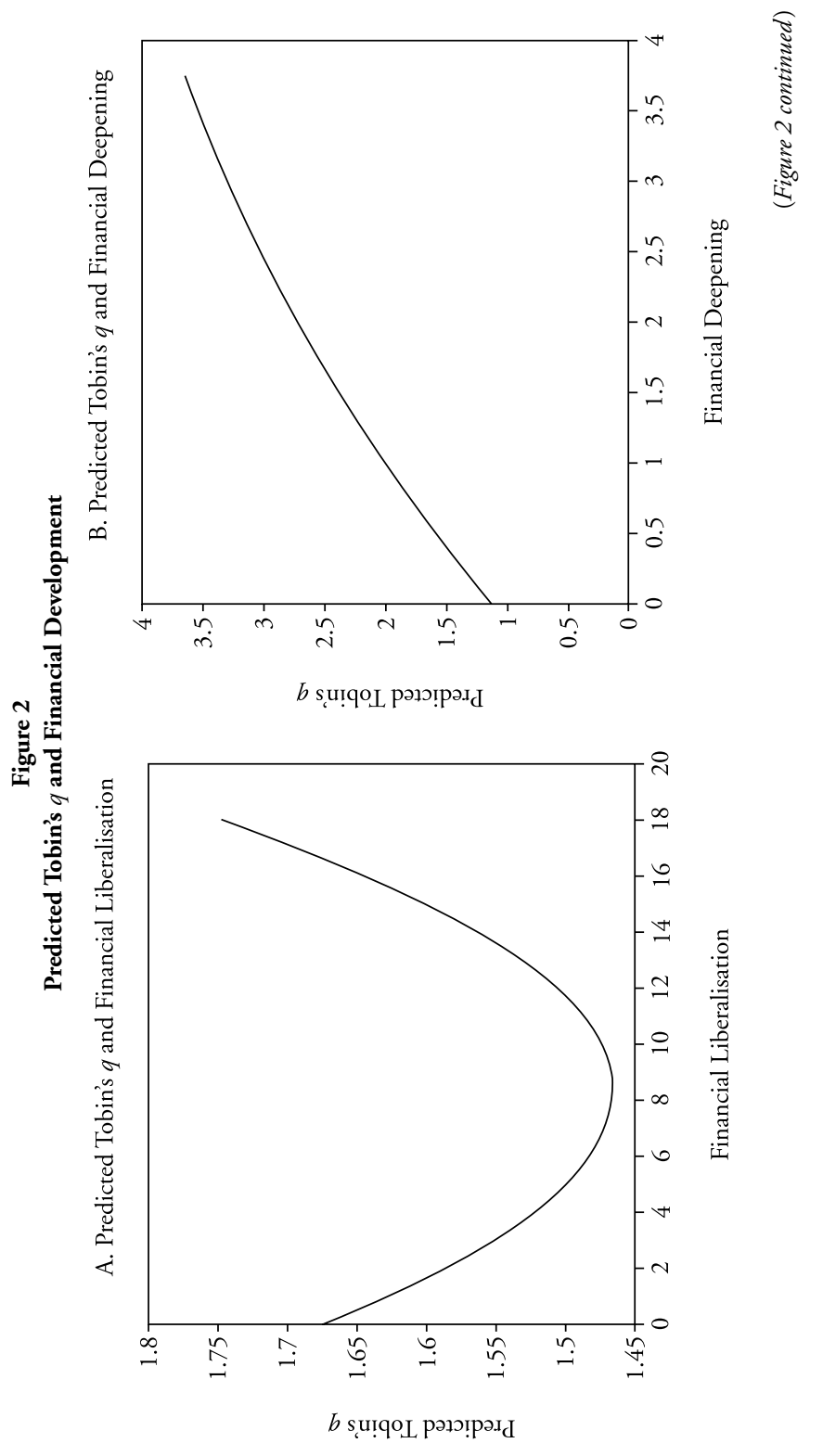



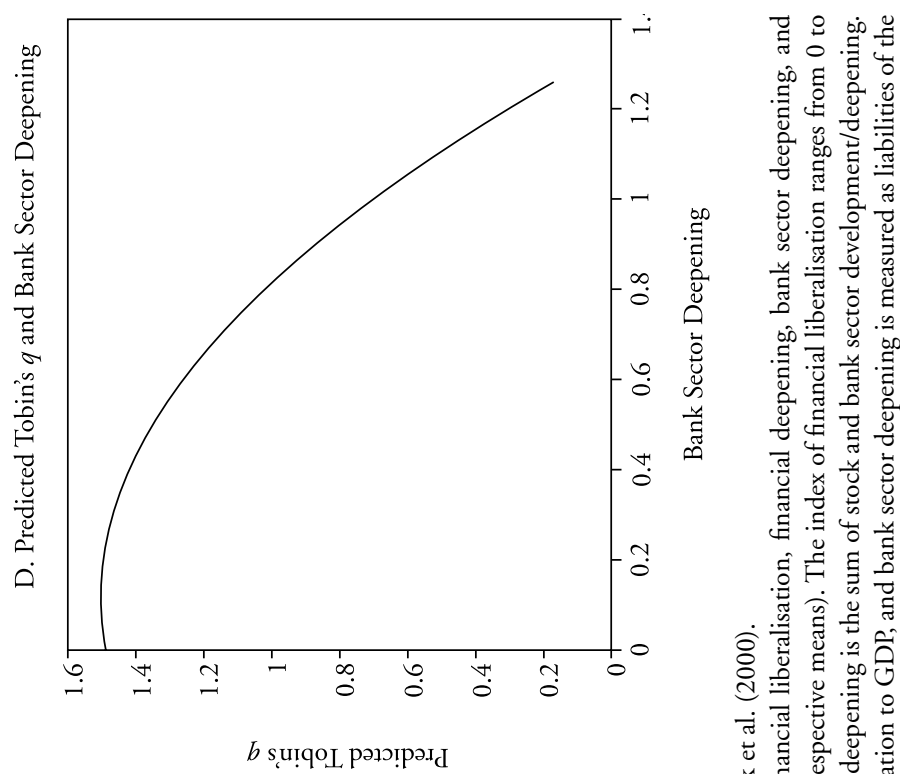

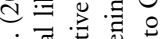

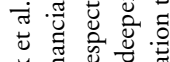

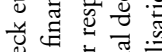

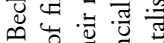

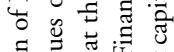

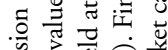

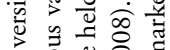



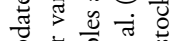

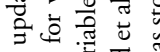

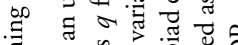

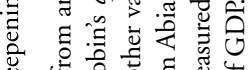

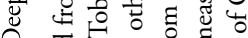
$\because$ రु

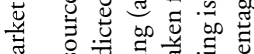
茫 $\sum$ ๘ 绻 을 可 过 可

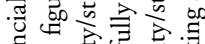

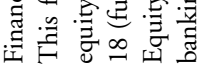

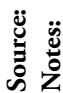


First, initially financial liberalisation destroys value, but beyond a certain level of financial liberalisation, firm value increases (the coefficient estimate on the financial liberalisation variable is significantly negative and the squared term is significantly positive). Beyond 8.33 , financial liberalisation tends to increase value. ${ }^{18}$ In contrast, financial deepening, or more precisely equity deepening enhances value, but at a decreasing rate (the coefficient estimates on the financial deepening and equity deepening variables are significantly positive, while the squared terms are statistically positive). Finally, bank deepening has the greatest wealth destroying effects at high levels of bank sector deepening, but does create value at very low levels of bank sector deepening, i.e., less than $0.106 .{ }^{19}$

\subsection{Regression estimates by level of financial deepening}

Next I examine how the level of financial deepening impacts on how financial liberalisation reforms cause firm value. For example, it is plausible that stock market reforms, e.g., opening domestic firms to foreign ownership is likely to be more effective where the stock market is deep and liquid..$^{20}$ Of course, one might argue that when the financial system is fully/well liberalised, then stock/credit markets are likely to be well developed. Consequently, one might argue that the analysis presented here is no different to the analysis presented in Table 4 (and Appendix 1). However, this is not necessarily the case. Specifically, while above-median financial development is associated with a median financial liberalisation value of 14 , the minimum value is 1.75 with a standard deviation of 2.82, which of course suggests that factors other than financial liberalisation promotes deeper capital markets. ${ }^{21}$ Of course, this also suggests that financial liberalisation does not always lead to deeper financial markets. The results are presented in Table 5.

\footnotetext{
${ }^{18}$ Partially differentiating Equation (2) yields $\left(\frac{\partial q}{\partial \text { FinLib }}\right)=\gamma_{1}+2 \gamma_{2}$ FinLib $=-0.05+$
$2(0.003)$ FinLib $=0 \Rightarrow$ FinLib $\simeq 8.33$.

The function is at a minimum at 8.33 since the second derivative is positive.

${ }_{19}\left(\frac{\partial q}{\partial \text { FinLib }}\right)=\gamma_{3}+2 \gamma_{4}$ BankDeep $=0.212+2(-0.999)$ BankDeep $=0 \Rightarrow$ BankDeep $\simeq 0.106$.

The function is at a maximum at 0.106 since the second derivative is negative.

${ }^{20}$ Financial deepening is also likely to proxy for other factors, e.g., the efficiency of the legal system, the strength of shareholder rights and institutional development. In this regard, given the opening of domestic stock markets to foreign owners, the benefits are likely to be greater where country/corporate governance is strong.

${ }^{21}$ Refer to Footnote 3.
} 


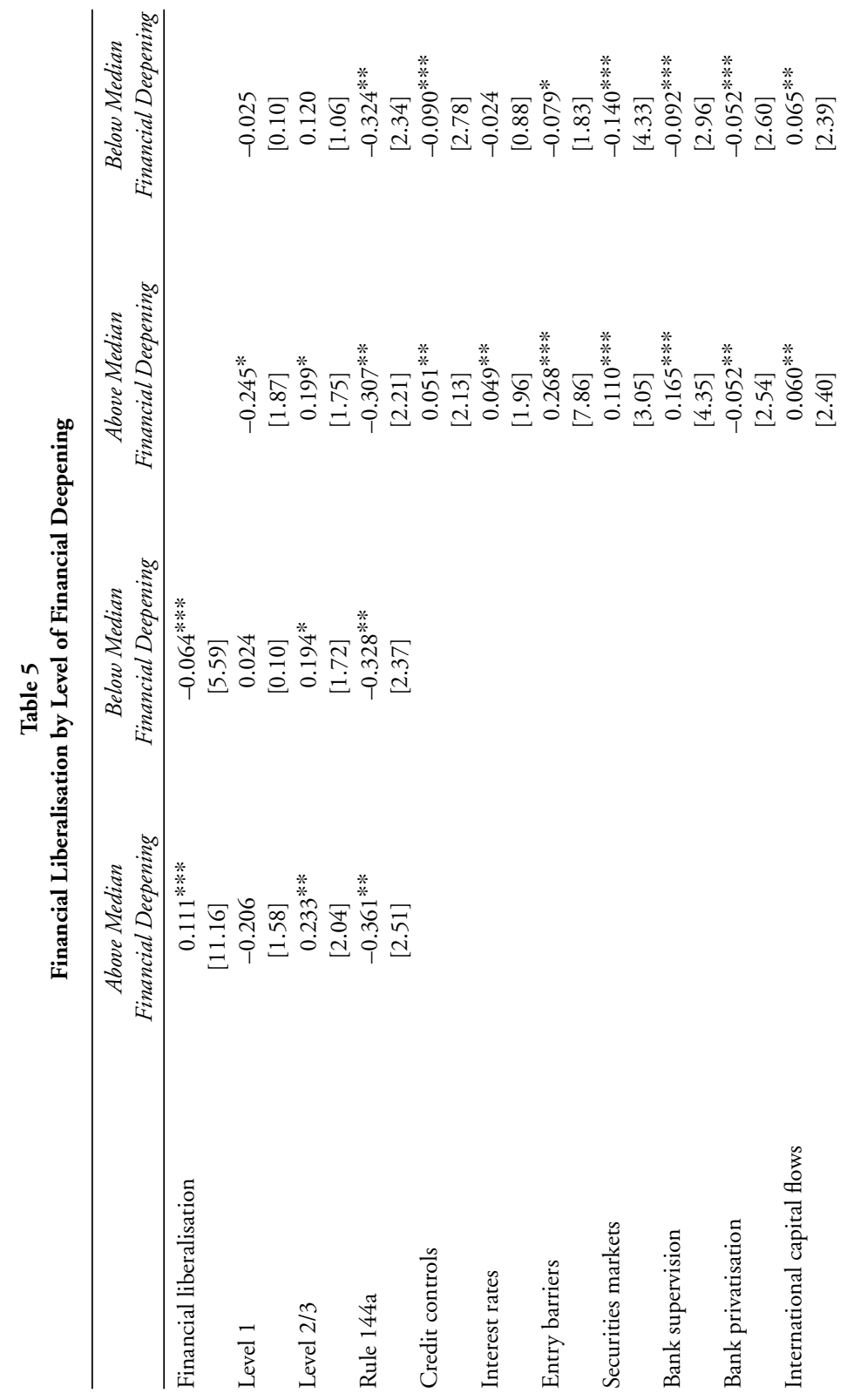







In Table 5, I present two sets of estimates: First, I regress Tobin's $q$ on the financial liberalisation index and the cross-listing dummy variables by level of financial deepening. In the remaining columns, I replace the financial liberalisation index with its components. As expected, financial liberalisation tends to increase value when financial depth is strong, and serves to reduce value when financial markets are not well developed. Furthermore, the effects are economically large, i.e., the implied absolute change in Tobin's $q$ is 0.765 , where financial depth is strong, and an absolute depreciation of 0.594 in value where financial depth is weak. In addition, the results also show that the benefits from cross-listing as a Level 2/3 ADR is greater where financial deepening is strong when financial markets are deep. This is consistent with Hope et al. (2007) who theorise that the net benefits to cross-listing are greater for these firms, since the costs of listing are likely to be considerably less for them.

In the remaining columns of Table 5, I undertake the same analysis, but now using the individual components of the financial liberalisation index. The results for the combined liberalisation index are largely reflected in the coefficient estimates on the components of the index. In summary, with the exception of the privatisation of the banking sector and international capital flows, the components of the liberalisation reflect the behaviour of the combined index, i.e., value increasing (decreasing) where financial depth is strong (weak). The largest gains come from a reduction in entry barriers (0.669 or 47.79 per cent) and the greatest decrease from stock market reforms ( 0.191 or 15.79 per cent). In contrast, privatisation of the banking sector always destroys value, while greater capital flows always increases value, although in both instances, the implied change in Tobin's $q$ is economically small (i.e., 0.029 or 2.07 per cent and 0.023 or 1.90 per cent for bank privatisation and 0.033 or 2.36 per cent and 0.025 or 2.07 per cent for international capital flows).

\subsection{Components of Tobin's $q$}

In the remainder of this article, I concentrate on examining how the components of Tobin's $q$ change in response to enhanced financial development, namely, financial liberlisation and deepening, and international cross-listings. I do so, since by examining the components of Tobin's $q$, it will provide a clearer picture of why, for example, financial liberalisation enhances firm value. On the one hand, liberalisation may enhance value because growth in total assets is outstripped by growth in market capitalisation. In fact, this is

Journal of Emerging Market Finance, 10:1 (2011): 21-71 
what Mitton and O'Connor (2010) find in their study, while Gozzi et al. (2008) find that asset growth outstrips growth in market capitalisations, which ensures that there are no long-term/permanent valuation gains to becoming an international firm.

In Table 6, I re-estimate Equation (1) where each of the variables is as before but now either total assets or market capitalisation is the dependent variable as indicated. Both variables are expressed in logs of US\$. In all regressions, I only include the control for firm growth, since including Global industry $q$, and especially firm size, would make little sense in these regressions. I present six separate regressions for each of the components of Tobin' q: in the first three, I regress each dependent variable on each of the main financial development variables, namely, financial liberalisation, financial deepening, and the cross-listing dummy variables, respectively. In the remaining columns, I present estimates for the components of financial deepening. The results suggest the following: First, financial deepening and international crosslistings are associated with large-scale corporate expansion. The latter has previously been documented by Gozzi et al. (2008). Interestingly, financial liberalisation is not associated with corporate expansion. On the contrary, I find that financial liberalisation is associated with lower firm size. These results hold in all four regressions. Changes in market capitalisation also follow a similar pattern: Financial deepening and international crosslistings (bar Rule 144a issues) lead to permanent increases in market capitalisations, which is consistent with Gozzi et al. (2008). In contrast, financial liberalisations are not associated with a permanent increase in market capitalisation. Taken together, the results suggest that the valuation gains from financial liberalisations result solely from reduced corporate size. In contrast, the valuation gains from both financial deepening and financial internationalisation, via depositary receipt programmes, result from increases in both corporate size and market capitalisations, where the increase in market capitalisations outweighs the increase in corporate size. In the bottom rows of Table 6 , I provide estimates of the economic significance of each. Interestingly, non-exchange traded depositary receipt issues (i.e., Level 1 and Rule 144a issues) lead to the greatest increases in firm size, but not surprisingly, the smallest increases in market capitalisations. Both financial deepening and Level $2 / 3$ depositary receipts lead to the largest market capitalisation appreciations. ${ }^{22}$

${ }^{22}$ In Appendix 2, I examine how the components of financial liberalisation impacts on total assets and market capitalisation. In a nutshell, Table 3 suggested that value increases in 


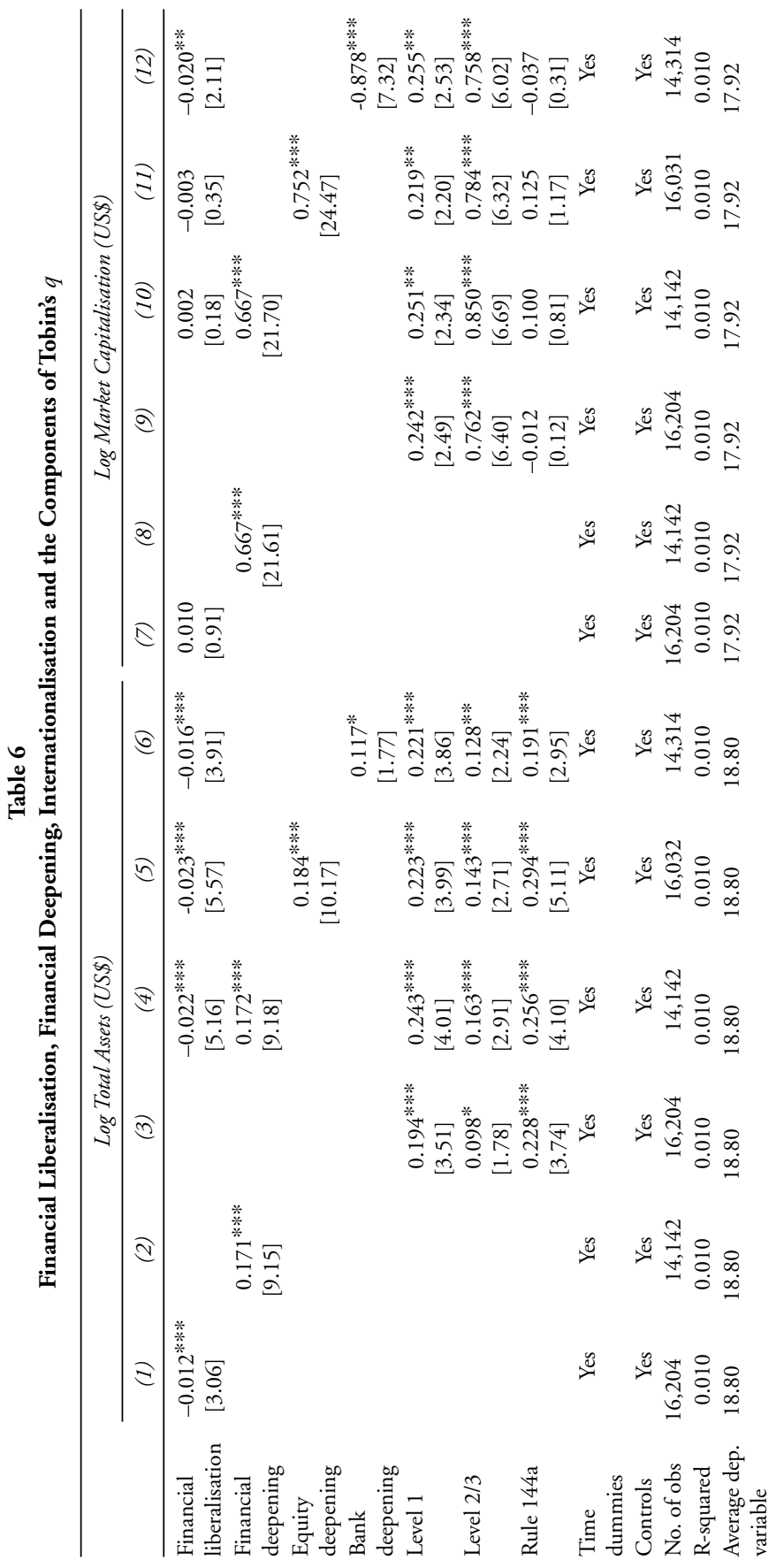




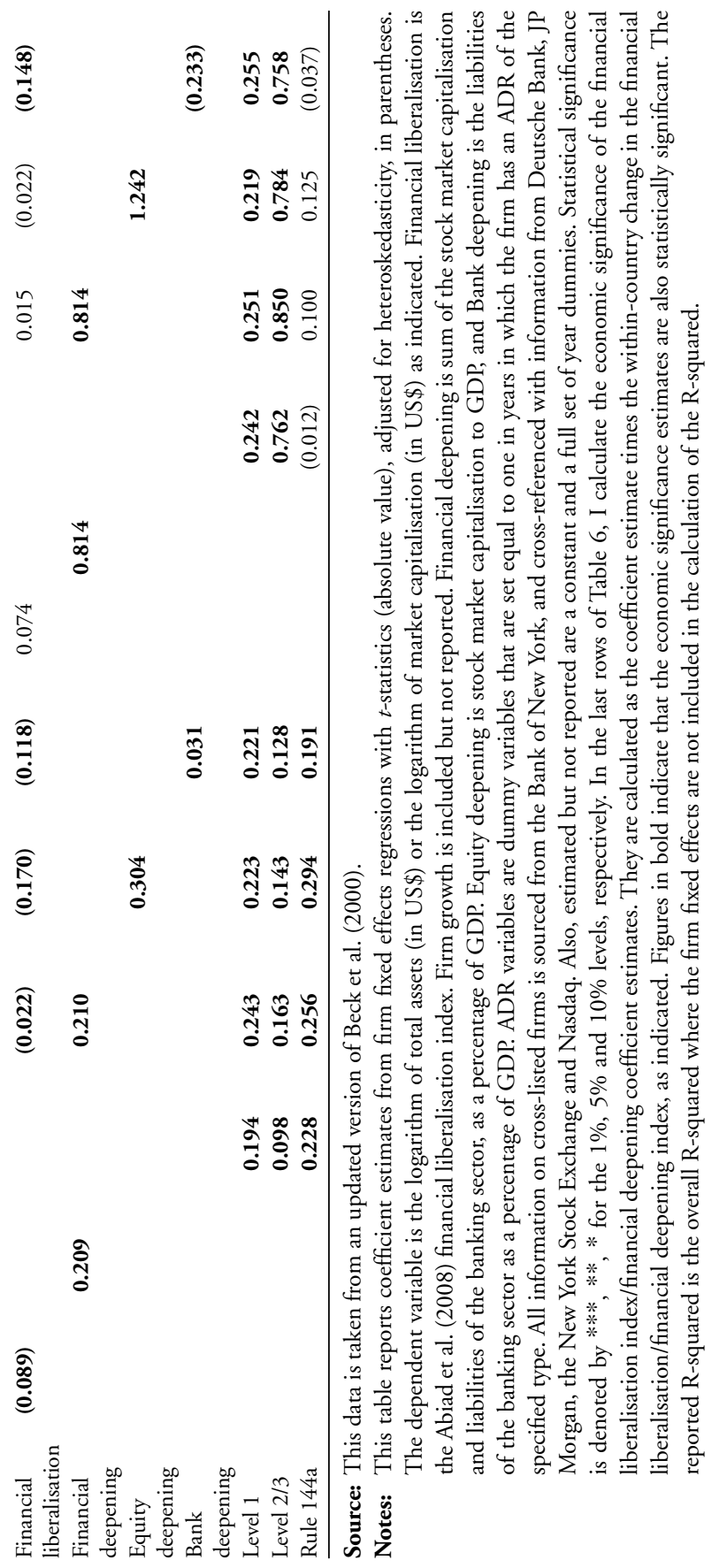


I supplement this analysis by re-estimating Equation (2), where again each of the variables is as before but now either total assets or market capitalisation is the dependent variable as indicated. Both variables are expressed in logs of US\$. As before, I only include the control for firm growth, since including Global Industry $q$, and especially firm size, would make little sense in these regressions. In Figures 3 and 4, the predicted total assets and market capitalisations against financial liberalisation, financial deepening, equity and bank sector deepening, respectively (with all other variables held at their respective means). ${ }^{23}$ The figures are in line with the results presented in Table 6, but do in themselves reveal some interesting findings. As suggested in Table 6, financial liberalisation is associated with increased market capitalisation, but lower firm size, resulting in greater firm value. Financial deepening is associated with increases in firm size and market capitalisations, and the trends for financial deepening as a whole, are similar to those outlined for equity market deepening. Finally, while bank sector deepening is associated with lower values of market capitalisations, and growth in assets, these trends do not manifest immediately. In fact, low/initial levels of bank sector deepening are associated with increases in market capitalisations and reductions in total assets. Beyond certain points, these trends are reversed and tend to dominate. The net result is that bank sector deepening tends to reduce firm value.

The fall in firm size associated with financial liberalisation is consistent with the findings of Abiad et al. (2004) that financial liberalisation is associated with a more efficient allocation of capital, which ultimately benefits small

deregulation of interest rates, a reduction in entry barriers, bank supervision and international capital flows, while security market reforms and greater banking supervision only served to reduce value. Appendix 2 provides greater clarity as to why these results manifest. What is really interesting from Appendix 2 is how firm value appreciations can come about differently, for example, from both interest rate deregulation and a reduction in entry barriers. In the case of the former, interest rate deregulation causes an increase in firm size (total assets) and market capitalisation, with presumably the latter growing quicker, resulting in an appreciation in value. A reduction in entry barriers increases firm value, not through an appreciation in market capitalisations, but solely from a reduction in firm size. The increase in firm value arising from greater international capital flows arises similarly to the valuation gains that arise from interest rate deregulation. Finally, both security market reforms and bank privatisation reduce value primarily since growth rate of assets presumably outstrips the growth in market capitalisations, although in the case of the former, market capitalisation actually decreases with reform.

${ }^{23}$ The coefficient estimates from these regressions are unreported but are available from me upon request.

Journal of Emerging Market Finance, 10:1 (2011): 21-71 






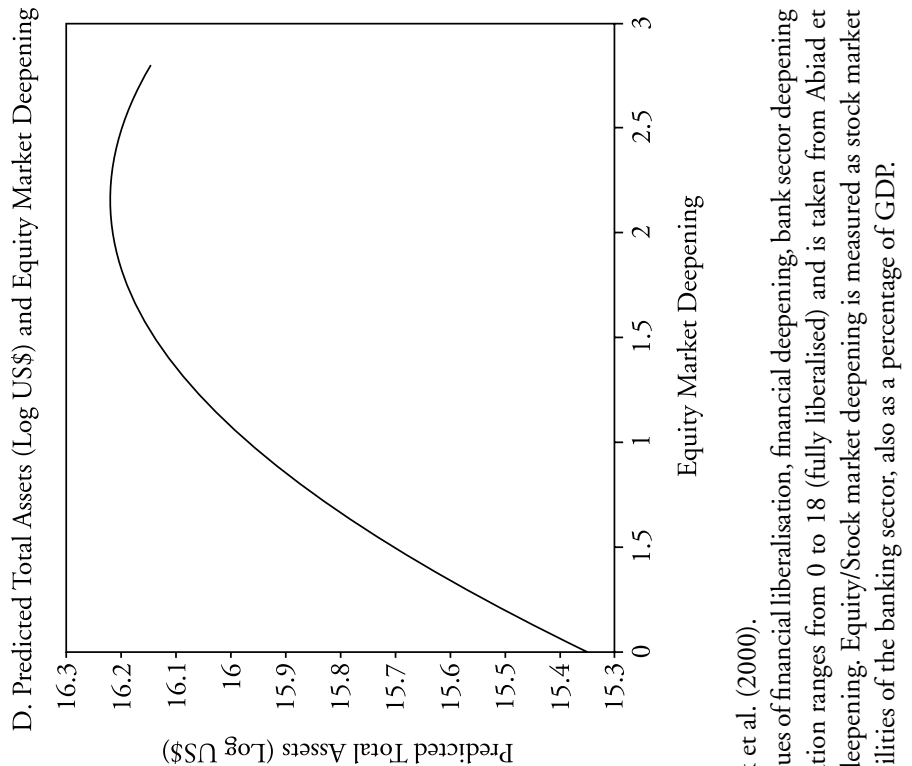

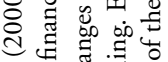



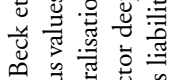

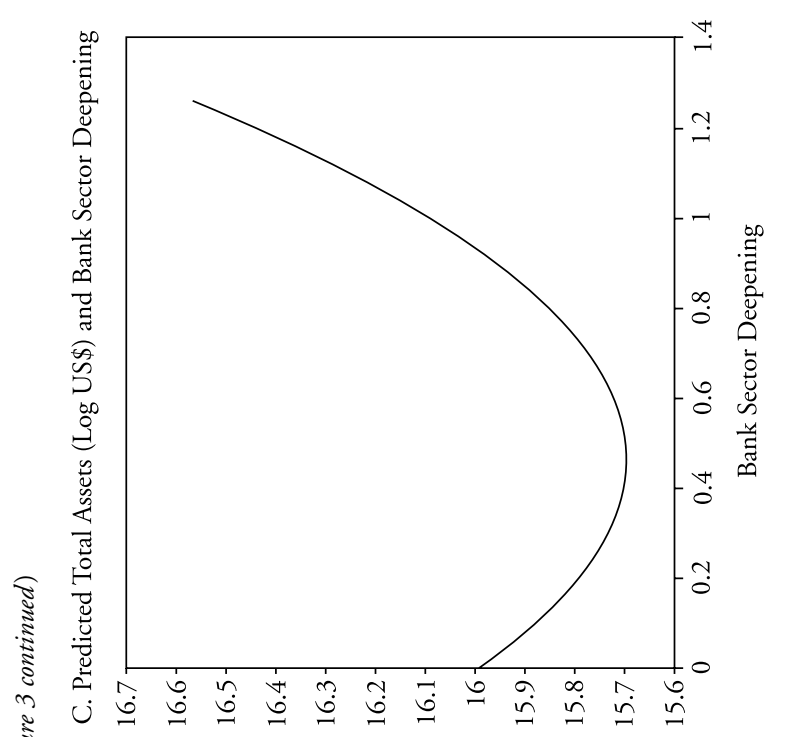

Ч.



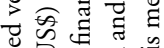
䒕 일 可 ปี

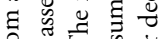
艺 ర్ 可 苍

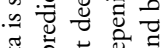

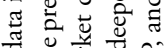

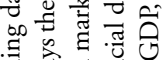
츨 증 ०ิ ठ․ 导式这

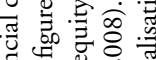
ปี

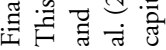
苑

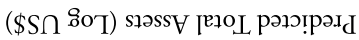




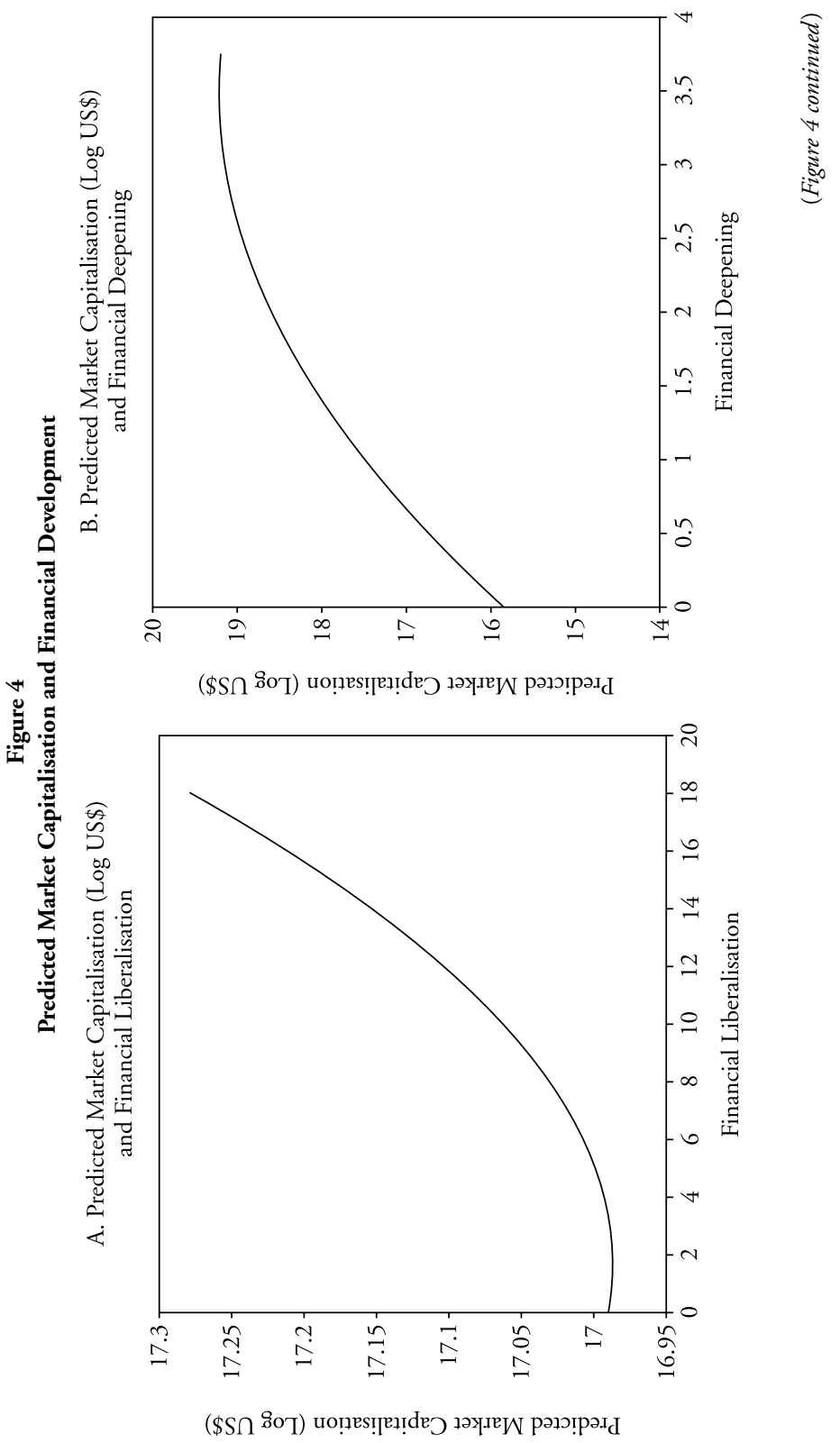




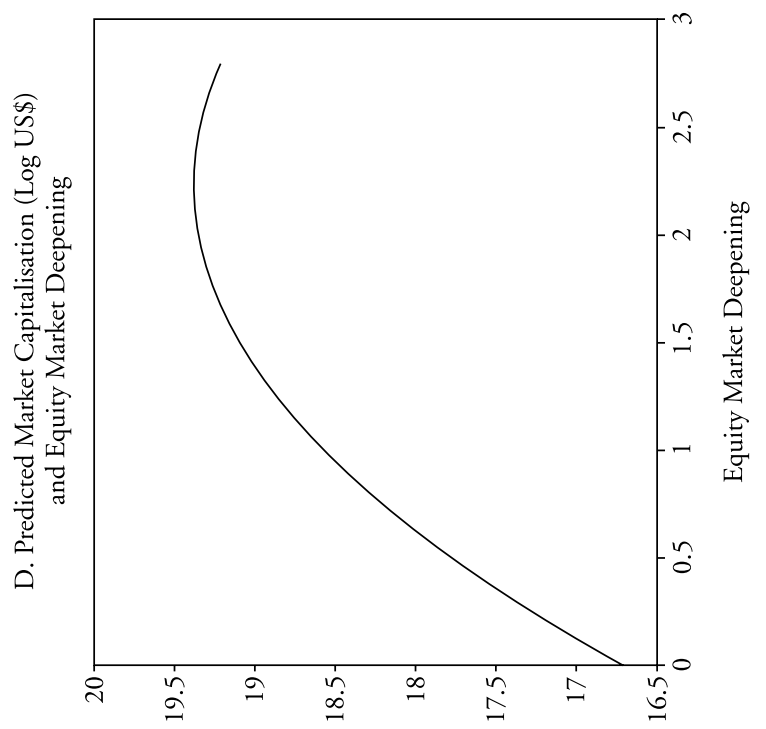

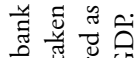

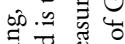

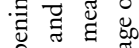
चे चे

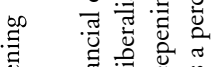
जี 월 तु 㱐通 串交

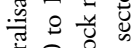

造 을

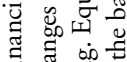
ज正 岁 $\approx$ 部

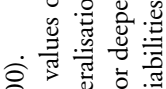

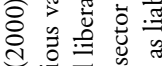

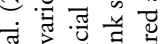

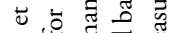

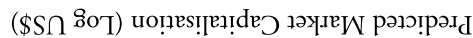

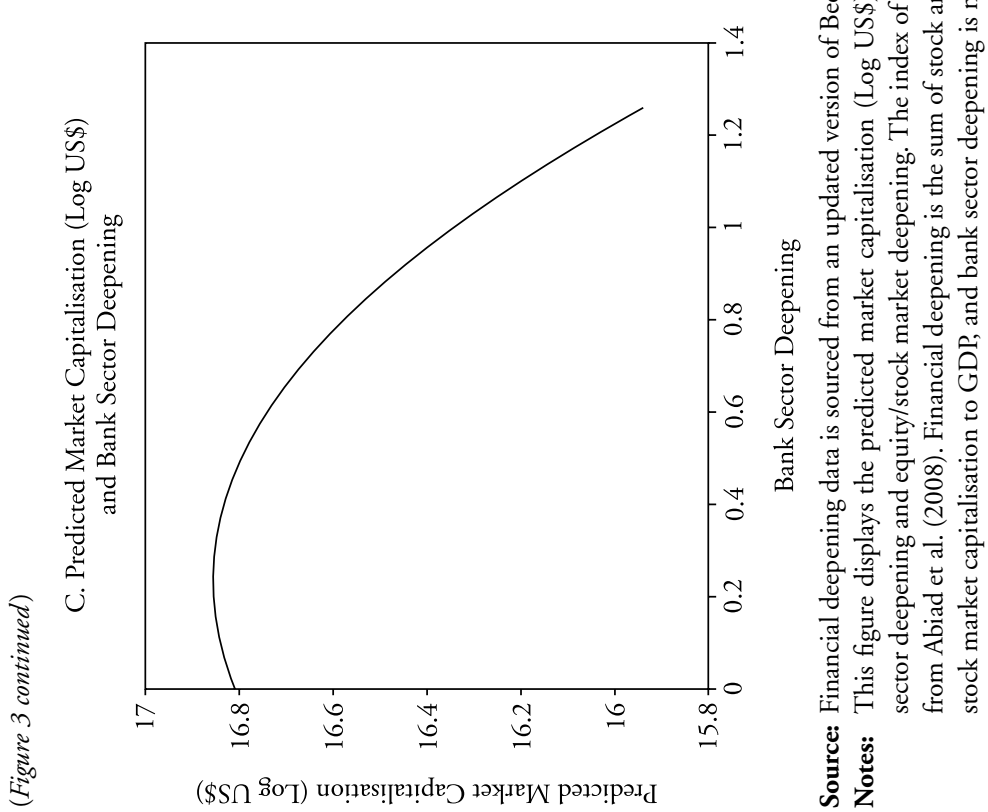


firms. Since smaller, younger firms tend to be financially constrained, in part because of poor financial development, financial development/liberalisation is likely to reduce their financial constraints, faciliate their growth and increase their size (Christoffersen et al. 2006; Laeven 2003). In contrast, larger firms are likely to be less financially constrained and are less likely to benefit from financial liberalisation. In fact, given poor financial development, large firms are able to reaffirm their competitive advantage over small firms within the same industry. However, given firm dynamics and competitive (industry) interactions, this is likely to be reversed; small firms grow, and the growth of large firms decreases (Costantini 2008). Since our sample of firms is largely made up of large firms, given the coverage of the Worldscope database, we observe this latter effect, i.e., the effect of financial liberalisation on the size of large firms.

\section{Concluding Remarks}

A large literature exists which suggests that financial development matters. While its detractors will point to the fact that financial liberalisation appears to increase the likelihood of banking crises, and make output more volatile in the short-term, it is generally well-accepted that financial liberalisation delivers long-term gains, both at the firm-level and collectively at the macroeconomic level. At the firm level, financial development is associated with, among other things, a relaxation of financing constraints, which ultimately promotes growth and investment. In this article, I seek to examine whether these gains manifest into higher value for these firms. I am partly motivated by recent work, which suggests that a certain aspect of financial liberalisation, namely, stock market liberalisations, enhances firm value (Mitton and O'Connor 2010). Here, I examine the valuation effects of other components of financial liberalisation reforms, and the valuation effects of financial liberalisation collectively. At least to the best of my knowledge, this has yet to be fully explored. The article also seeks to examine how both aspects of financial development, namely, liberalisation and deepening impact on firm value. Recent work suggests that they can have very differing effects on firm-level outcomes (Abiad et al. 2004). Finally, and in a similar vein, I seek to examine how the valuation gains from domestic financial development compare to the valuation gains that arise from internationalisations, for example, through international cross-listings in the US. The former is generally associated with 
what is commonly referred to as a cross-listing premium (Doidge et al. 2004, 2009). I compare how the valuation gains from listing abroad compare to the gains from domestic financial development. Schmukler and Vesperoni (2006) do likewise in their study of corporate debt maturity.

I find that financial development matters for firm value. Firm value increases in both financial liberalisation and financial deepening, although the latter provides the greatest valuation gains. For example, over the entire sample period, the implied change in Tobin' $q$ attributed to financial deepening is about five times as large as the change implied by financial liberalisation. Both impact positively on firm value, but financial deepening has a greater impact. Of course, since financial deepening is in part caused by financial liberalisation, the valuation premium assigned to deepening over liberalisation is likely to be overstated. Second, on closer inspection, I find that the valuation gains from financial deepening arise solely from equity market deepening. In contrast, bank sector deepening reduces firm value. Finally, like many others, I document a cross-listing premium for Level 2/3 ADRs. The implied gains from financial liberalisation are typically greater than the gains from financial internationalisation, but they are similar in magnitude over the period examined. Of course, these results then suggest that firms would benefit more, at least in terms of value, not from an international cross-listing, but from measures that promote greater financial deepening at home.

Thomas O'Connor, Department of Economics, Finance and Accounting, National University of Ireland Maynooth, Maynooth Co. Kildare, Ireland. E-mail: thomas.g. oconnor@nuim.ie 


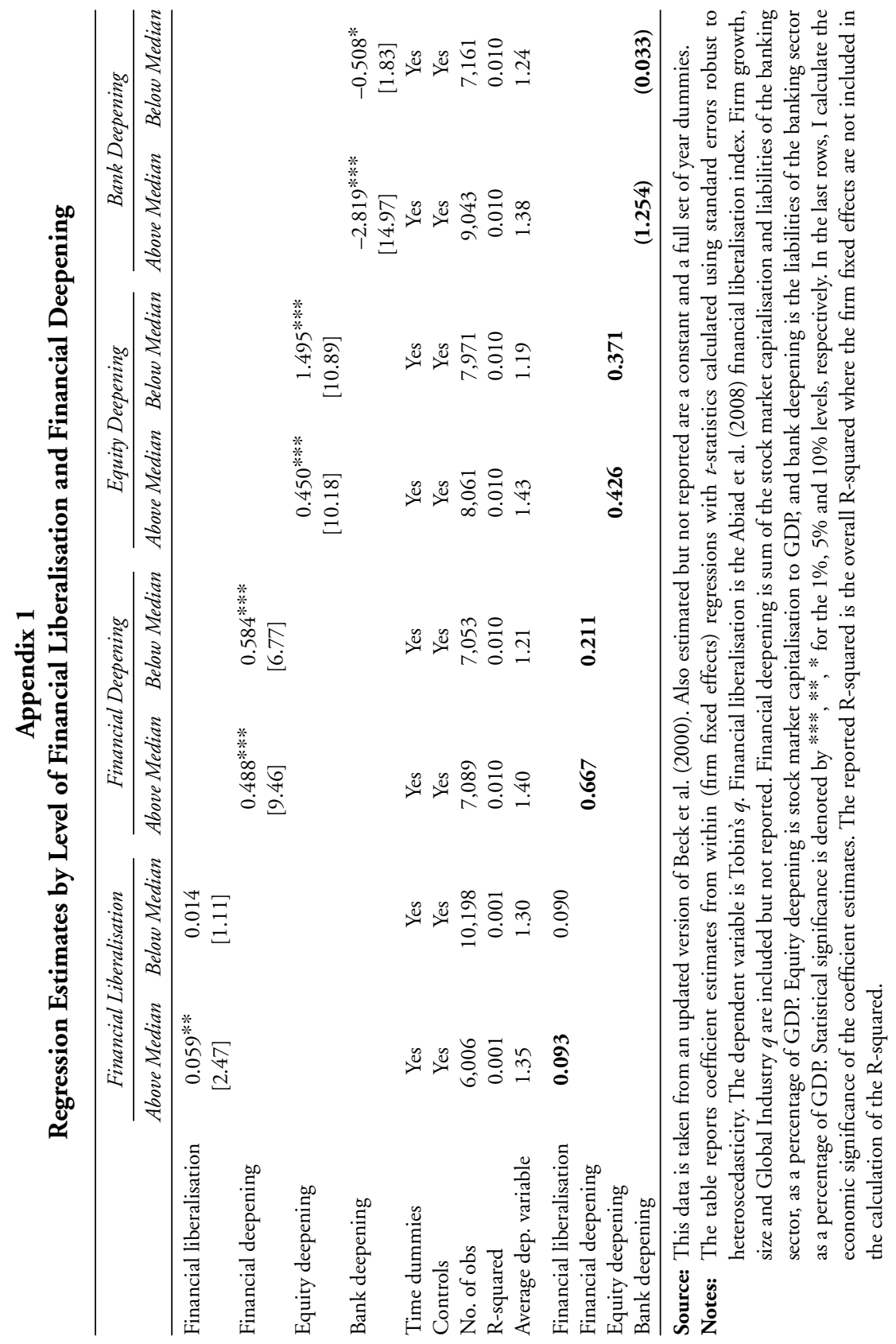




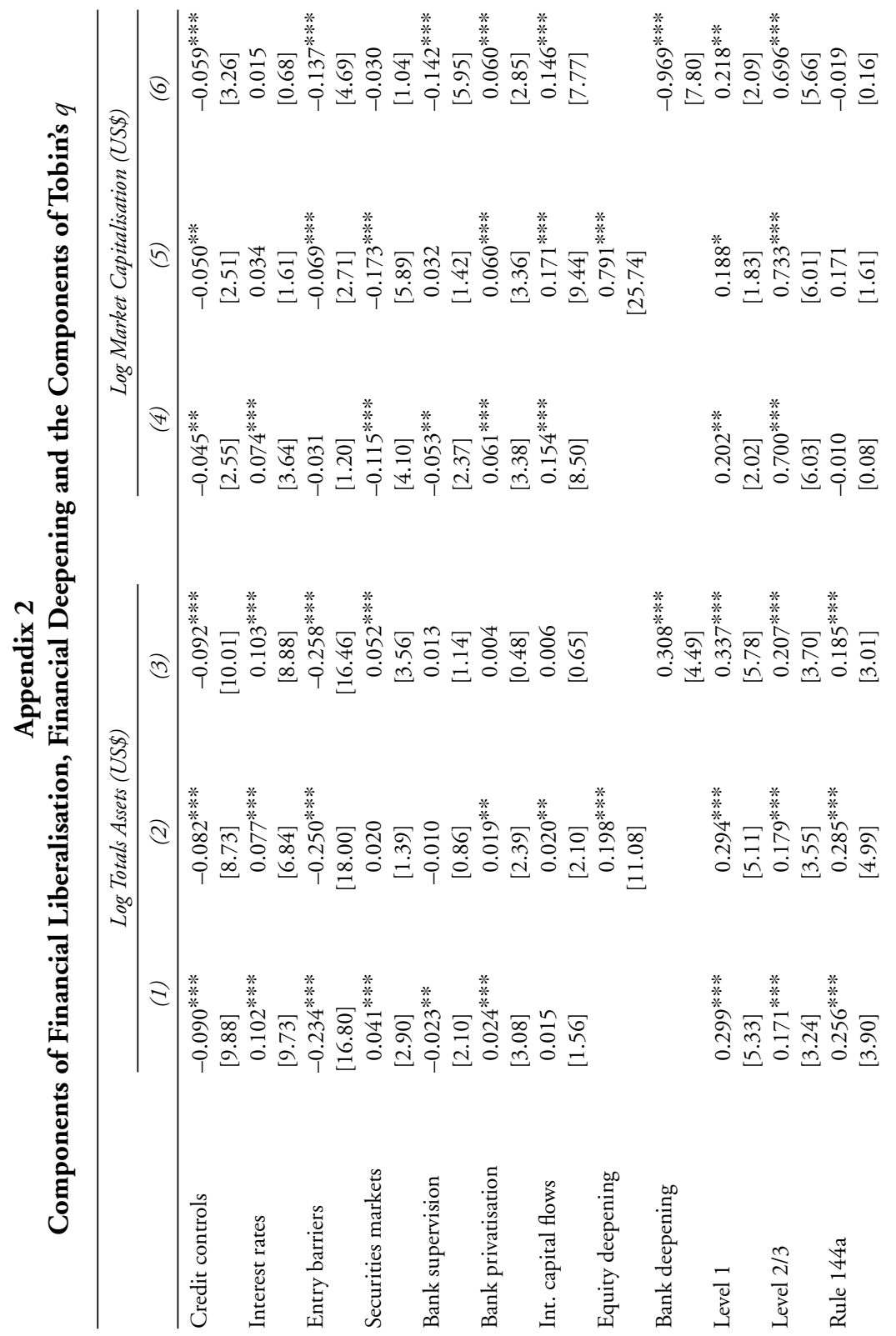




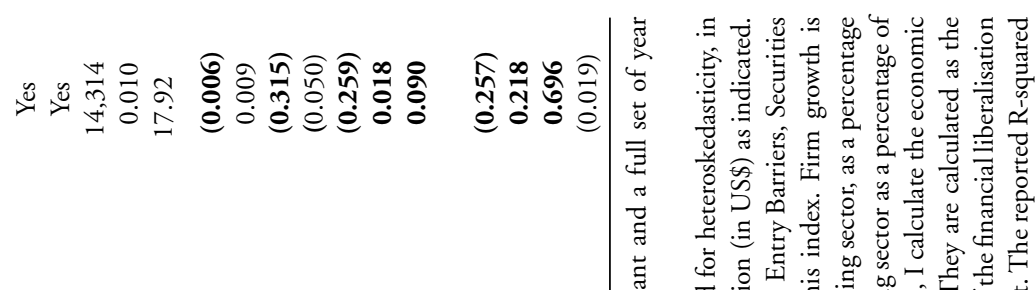

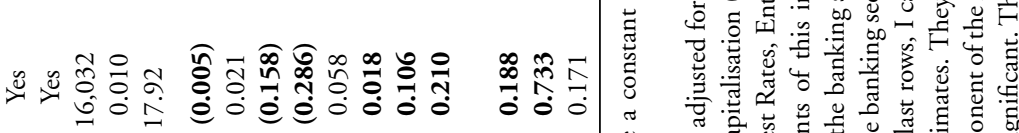

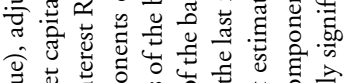

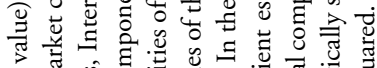

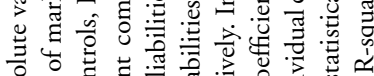



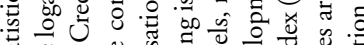

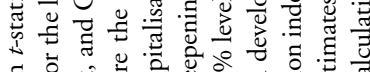
든

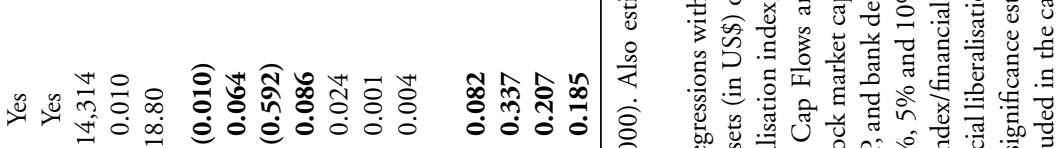

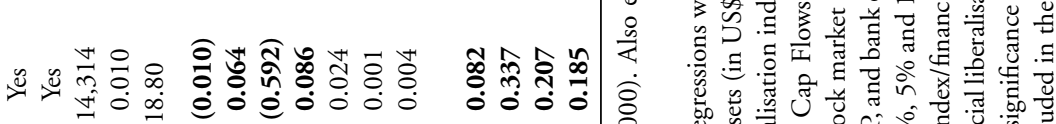

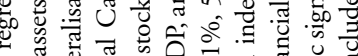

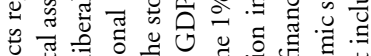

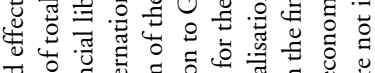

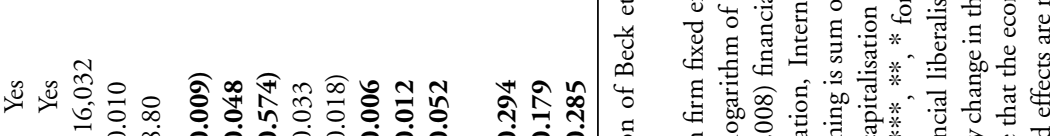

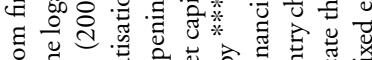

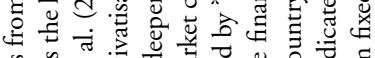
过



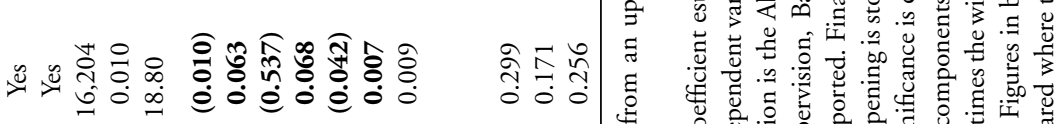

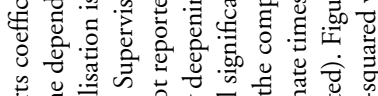

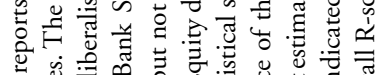

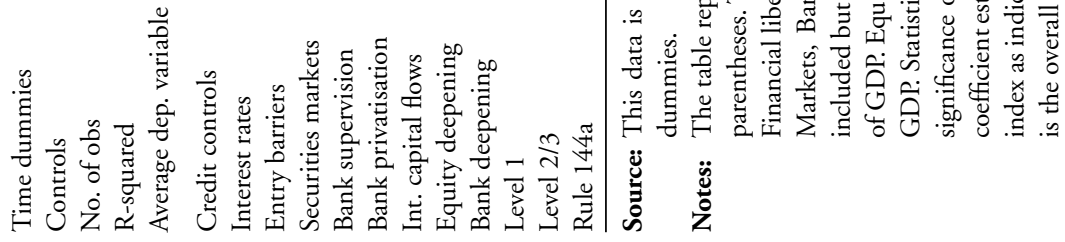




\section{References}

Abiad, A., N. Oomes and K. Ueda (2004), 'The Quality Effect: Does Financial Liberalisation Improve the Allocation of Capital?' IMF Working Paper 04/112, International Monetary Fund, Washington, DC.

Abiad, A., E. Detragiache and T. Tressel (2008), 'A New Database of Financial Reforms', IMF Working Paper No. 266, International Monetary Fund, Washington, DC.

Allen, F. and D. Gale (1999), 'Bubbles, Crises, and Policy', Oxford Review of Economic Policy, 15(3): 9-18.

(2000), 'Bubbles and Crises', Economic Journal, 110(460): 236-55.

Bebchuk, L., A. Cohen and A. Ferrell (2009), 'What Matters in Corporate Governance', Review of Financial Studies, 22(2): 783-827.

Beck, T., A. Demirguc-Kunt and R. Levine (2000), 'A New Database on Financial Development and Structure', World Bank Economic Review, 14(3): 597-605.

Beck, T. and R. Levine (2004), 'Stock Markets, Banks, and Growth: Panel Evidence', Journal of Banking and Finance, 28(3): 423-42.

Beck, T., A. Demirguc-Kunt and V. Maksimovic (2005), 'Financial and Legal Constraints to Growth: Does Firm Size Matter?', Journal of Finance, 60(1): 137-77.

Beck, T., A. Demirguc-Kunt, L. Laeven and V. Maksimovic (2006), 'The Determinants of Financing Obstacles', Journal of International Money and Finance, 25(3): 932-52.

Beck, T. and A. Demirguc-Kunt (2006), 'Small and Medium-size Enterprises: Access to Finance as a Growth Constraint', Journal of Banking and Finance, 30(11): 2931-43.

Beck, T., A. Demirguc-Kunt, L. Laeven and R. Levine (2008), 'Finance, Firm Size, and Growth', Journal of Money, Credit and Banking, 40(7): 1379-1405.

Benos, E. and M. Weisbach (2004), 'Private Benefits and Cross Listings in the U.S.', Emerging Markets Review, 5(2): 217-40.

Berger, A., A. Demirguc-Kunt, R. Levine and J. Haubrich (2004), 'Bank Concentration and Competition: An Evolution in the Making', Journal of Money, Credit, and Banking, 36(3): 433-51.

Bianconi, M. and L. Tan (2010), 'Cross-listing Premium in the US and UK Destination', International Review of Economics and Finance, 19(2): 244-59.

Billmeier, A. and I. Massa (2009), 'What Drives Stock Market Development in Emerging Markets-Institutions, Remittances, or Natural Resources?', Emerging Markets Review, 10(1): 23-35.

Booth, L., A. Aivazian, A. Demirguc-Kunt and V. Maksimovic (2001), 'Capital Structures in Developing Countries', Journal of Finance, 56(1): 87-130.

Boyd, J., R. Levine and B. Smith (2001), 'The Impact of Inflation on Financial Sector Performance', Journal of Monetary Economics, 47(2): 221-48.

Ceterolli, N. (2001), 'Competition among Banks: Good or Bad?', Federal Reserve Bank of Chicago Economic Perspectives, 2nd Quarter: 38-48.

Christoffersen, P., H. Chung and V. Errunza (2006), 'Size Matters: The Impact of Financial Liberalisation on Individual Firms', Journal of International Money and Finance, 25(8): 1296-1318.

Chua, C.T., C.S. Eun and S. Lai (2006), 'Corporate Valuation Around the World: The Effects of Governance, Growth and Openness', Journal of Banking and Finance, 31(1): 35-56.

Journal of Emerging Market Finance, 10:1 (2011): 21-71 
Claessens, S. and L. Laeven (2004), 'What Drives Bank Competition? Some International Evidence', Journal of Money, Credit, and Banking, 36(3): 563-83.

Claessens, S., D. Klingebiel and S. Schmukler (2006), 'Stock Market Development and Internationalisation: Do Economic Fundamentals Spur Both Similarly?', Journal of Empirical Finance, 13(3): 316-50.

Cornett, M., L. Guo, S. Khaksari and H. Tehranian (2010), 'The Impact of State Ownership on Performance Differences in Privately-owned versus State-owned Banks: An International Comparison', Journal of Financial Intermediation, 19(1): 74-94.

Costantini, J. (2008), 'Impact of Financial Development on Firm Growth and Firm Size', Unpublished Working Paper, INSEAD, Paris.

De la Torre, A. and S. Schmukler (2006), Emerging Capital Markets and Globalization: The Latin American Experience. Washington, DC: Stanford University Press, Palo Alto, and The World Bank.

De la Torre, A., J.C. Gozzi and S. Schmukler (2007), 'Stock Market Development under Globalization: Whiter the Gains from Reforms', Journal of Banking and Finance, 31(6): 1731-54.

Demirguc-Kunt, A. and R. Levine (1996), 'Stock Markets, Corporate Finance, and Economic Growth: An Overview', The World Bank Economic Review, 10(2): 223-39.

Demirguc-Kunt, A. and V. Maksimovic (1998), 'Law, Finance, and Firm Growth', The Journal of Finance, 53(6): 2107-37.

Demirguc-Kunt, A. and E. Detragiache (1999), 'Financial Liberalisation and Financial Fragility', in Boris Pleskovic and Joesph E. Stiglitz (eds), Annual World Bank Conference on Development Economics 1998, pp. 96-122. Washington, DC: The World Bank.

Doidge, C., G. Karolyi and R. Stulz (2004), 'Why are Foreign Firms Listed in the U.S. Worth More?', Journal of Financial Economics, 71(2): 205-38.

- (2009), 'Has New York Become Less Competitive in Global Markets? Evaluating Foreign Listing Choices over Time', Journal of Financial Economics, 91(3): 253-77.

Fazzari, S., G. Hubbard and B. Petersen (1988), 'Financing Constraints and Corporate Investment', Brookings Papers on Economic Activity, 19(1): 141-206.

Ferris, S., K. Kim and G. Noronha (2009), 'The Effects of Cross Listing on Corporate Governance: A Review of the International Evidence', Corporate Governance: An International Review, 17(3): 338-52.

Flavin, T.J. and T.G. O'Connor (2010), 'The Sequencing of Stock Market Liberalisation Events and Corporate Financing Decisions', Emerging Markets Review, 11(3): 183-204.

Forbes, K. (2007), 'One Cost of the Chilean Capital Controls: Increased Financing Constraints for Smaller Traded Firms', Journal of International Economics, 71(2): 294-323.

Giannetti, M. (2003), 'Do Better Institutions Mitigate Agency Problems? Evidence from Corporate Financing Choices', Journal of Financial and Quantitative Analysis, 38(1): $185-212$.

Giannetti, M. and S. Ongena (2009), 'Financial Integration and Firm Performance: Evidence from Foreign Bank Entry in Emerging Markets', Review of Finance, 13(2): 181-223.

Gompers, P.A., J.L. Ishii and A. Metrick (2003), 'Corporate Governance and Equity Prices', Quarterly Journal of Economics, 118(1): 107-55.

Gormley, T. (2010), 'The Impact of Foreign Bank Entry in Emerging Markets: Evidence from India', Journal of Financial Intermediation, 19(1): 26-51. 


\section{0 / Thomas O’Connor}

Gozzi, J.C., R. Levine and S. Schmukler (2008), 'Internationalisation and the Evolution of Corporate Valuation', Journal of Financial Economics, 88(3): 607-32.

- (2010), 'Patterns of International Capital Raisings', Journal of International Economics, 80(1): 45-57.

Harrison, A., I. Love and M. Macmillan (2004), 'Global Capital Flows and Financing Constraints', Journal of Development Economics, 75(1): 269-301.

Henry, P. (2000), 'Do Stock Market Liberalisations Cause Investment Booms?', Journal of Financial Economics, 58(1-2): 301-34.

Hope, O., T. Kang and Y. Zang (2007), 'Bonding to the Improved Disclosure Environment in the United States: Firms' Listing Choices and their Capital Market Consequences', Journal of Contemporary Accounting and Economics, 2(2): 1-33.

Kaminsky, G.L. and S. Schmukler (2008), 'Short-run Pain, Long-run Gain: Financial Liberalization and Stock Market Cycles', Review of Finance, 12(2): 253-92.

Karolyi, G.A. (2004), 'The Role of American Depositary Receipts in the Development of Emerging Equity Markets', Review of Economics and Statistics, 86(3): 670-90.

- (2006), 'The World of Cross Listings and Cross Listings of the World: Challenging Conventional Wisdom', Review of Finance, 10(1): 99-152.

(2010), 'Corporate Governance, Agency Problems, and International Cross-listings: A Defense of the Bonding Hypothesis', Unpublished Working Paper, Cornell University, Ithaca, NY.

Khurana, I.K., X. Martin and R. Pereira (2006), 'Financial Development and the Cash Flow Sensitivity of Cash', Journal of Financial and Quantitative Analysis, 41(4): 787-807. (2008), 'Cross-listing and Firm Growth', Review of Finance, 12(2): 293-322.

Laeven, L. (2001), 'Insider Lending and Bank Ownership: The Case of Russia', Journal of Comparative Economics, 29(2): 207-29.

_ (2003), 'Does Financial Liberalisation Reduce Financing Constraints?', Financial Management, 32(1): 5-34.

La Porta, R., F. Lopez-de-Silanes, A. Shleifler and R. Vishny (1997), 'Legal Determinants of External Financing', Journal of Finance, 52(3): 1131-50.

(1998), 'Law and Finance', Journal of Political Economy, 106(6): 1113-55.

Levine, R. (1991), 'Stock Markets, Growth and Tax Policy', Journal of Finance, 46(4): $1445-65$.

- (1998), 'The Legal Environment, Banks, and Long-run Economic Growth', Journal of Money, Credit, and Banking, 30(2): 596-613.

- (2001), 'International Financial Liberalisation and Economic Growth', Review of International Economics, 9(4): 688-702.

Levine, R. and S. Zervos (1998), 'Stock Markets, Banks, and Economic Growth', American Economic Review, 88(3): 537-58.

Levine, R. and S. Schmukler (2007), 'Migration, Spillovers, and Trade Diversion: The Impact of Internationalisation on Domestic Stock Market Activity', Journal of Banking and Finance, 31(6): 1595-1612.

Li, K. (2007), 'The Growth in Equity Market Size and Trading Activity: An International Study', Journal of Empirical Finance, 14(1): 59-90.

Lins, K., D. Strickland and M. Zenner (2005), 'Do Non-U.S. Firms Issue Equity on U.S. Stock Exchanges to Relax Capital Constraints?', Journal of Financial and Quantitative Analysis, 40(1): 109-33.

Journal of Emerging Market Finance, 10:1 (2011): 21-71 
Love, I. (2003), 'Financial Development and Financing Constraints: International Evidence from the Structural Investment Model', Review of Financial Studies, 16(3): 765-91.

Mitton, T. (2006), 'Stock Market Liberalisation and Operating Performance at the Firm Level', Journal of Financial Economics, 81(3): 625-47.

Mitton, T. and T. O'Connor (2010), 'Investability and Firm Value', European Financial Management (forthcoming).

Moel, A. (2001), 'The Role of American Depositary Receipts in the Development of Emerging Markets', Economia, 2(1): 209-73.

O'Connor, T. (2009a), 'The Valuation Effects of Cross-listing Abroad for Irish Firms', The Irish Accounting Review, 16(1): 55-87.

(2009b), 'Does Cross Listing in the U.S. Really Enhance the Value of Emerging Market Firms?', Review of Accounting and Finance, 8(3): 308-36.

Rajan, R. and L. Zingales (1998), 'Financial Dependence and Growth', American Economic Review, 88(3): 559-86.

(2003), 'The Great Reversals: The Politics of Financial Development in the Twentieth Century', Journal of Financial Economics, 69(1): 5-50.

Reese, W. and M. Weisbach (2002), 'Protection of Minority Shareholder Interests, Cross-listings in the United States, and Subsequent Equity Offerings', Journal of Financial Economics, 66(1): 65-104.

Sarkissian, S. and M.J. Schill (2009), 'Are There Permanent Valuation Gains to Overseas Listings?', Review of Financial Studies, 22(1): 371-412.

(2010), 'Cross Listing Waves and the Search for Value Gains', Unpublished Working Paper, McGill University, Montreal, Quebec.

Schmukler, S.L. and E. Vesperoni (2006), 'Financial Globalization and Debt Maturity in Emerging Markets', Journal of Development Economics, 79(1): 183-207.

Schneider, M. and A. Tornell (2004), 'Balance Sheet Effects, Bailout Guarantees, and Financial Crises', Review of Economic Studies, 71(3): 883-913.

Tressel, T. and E. Detragiache (2008), 'Do Financial Sector Reforms Lead to Financial Development? Evidence from a New Dataset', IMF Working Paper No. 265, International Monetary Fund, Washington, DC.

White, H. (1980), 'A Heteroskedasticity-consistent Covariance Matrix Estimator and a Direct Test for Heteroskedasticity', Econometrica, 48(4): 817-38. 